\title{
Accumulation and distribution of heavy metals in soil and food crops around the ship breaking area in southern Bangladesh and associated health risk assessment
}

\author{
Asma Binta Hasan ${ }^{1}$ - A. H. M. Selim Reza ${ }^{1}$ - Sohail Kabir ${ }^{1}$. Md. Abu Bakar Siddique ${ }^{2}$. Md. Aminul Ahsan ${ }^{2}$. \\ Md. Ahedul Akbor ${ }^{2}$
}

Received: 28 August 2019 / Accepted: 23 December 2019 / Published online: 4 January 2020

(c) Springer Nature Switzerland AG 2020

\begin{abstract}
Heavy metal pollution in agricultural soils and food crops around the ship breaking area is of great environmental and human health concern. In this work, we have spectroscopically determined the concentrations of $\mathrm{Cd}, \mathrm{Pb}, \mathrm{Fe}, \mathrm{Mn}, \mathrm{Zn}, \mathrm{Cr}$, $\mathrm{Cu}$, and $\mathrm{Ni}$ in agricultural soils and commonly consumed vegetables, fruits, and rice grain collected from the Sitakunda ship breaking area of Chittagong, Bangladesh, in order to evaluate their contamination levels and probable human health risk with a multivariate statistical approach. Multivariate analyses such as principal component analysis and cluster analysis of the analytical data indicate a significant metal contamination in the samples which could be attributed to industrial activities such as ship breaking. The results of soil contamination evaluation indices such as enrichment factor, geo-accumulation index, and contamination factor demonstrated that the soils around the ship breaking area are mainly contaminated by $\mathrm{Cd}, \mathrm{Pb}, \mathrm{Zn}$, and $\mathrm{Cu}$ while food crops were mostly contaminated by $\mathrm{Zn}, \mathrm{Cr}$, and $\mathrm{Cu}$. The $\mathrm{Pb}$ contaminated the olive and teasle gourd while $\mathrm{Cd}$ contamination in rice grain was at the threshold limit for health hazard. $\mathrm{Mn}$ was slightly accumulated in banana. Transfer coefficient values of $\mathrm{Cd}, \mathrm{Zn}$, and $\mathrm{Cu}$ for almost all food crops were higher than other metals, and $\mathrm{Cd}$ showed the highest transfer. Estimated daily intake values for $\mathrm{Ni}$ exceeded the standard limit $\left(1.3 \mu \mathrm{g} \mathrm{kg}^{-1} \mathrm{day}^{-1}\right)$. Target hazard quotient values of $\mathrm{Cu}, \mathrm{Zn}, \mathrm{Pb}$, and $\mathrm{Cd}$ indicate that the local inhabitants who consume the contaminated food crops are being exposed to potential health risks.
\end{abstract}

\footnotetext{
Electronic supplementary material The online version of this article (https://doi.org/10.1007/s42452-019-1933-y) contains
} supplementary material, which is available to authorized users.

Md. Abu Bakar Siddique, sagor.bcsir@gmail.com | 'Department of Geology and Mining, University of Rajshahi, Rajshahi 6205, Bangladesh. ${ }^{2}$ Institute of National Analytical Research and Service (INARS), Bangladesh Council of Scientific and Industrial Research (BCSIR), Dhanmondi, Dhaka 1205, Bangladesh. 


\section{Graphic abstract}

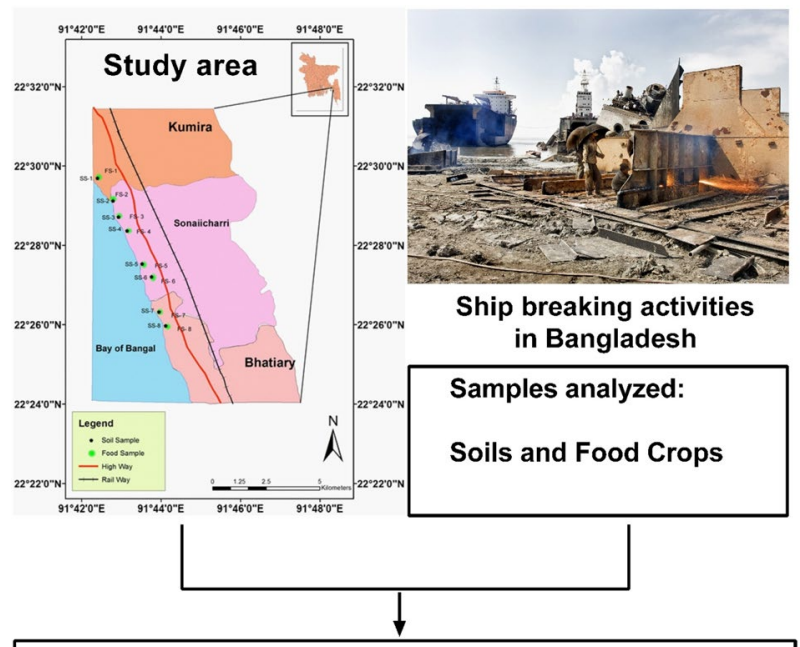

$>$ Analysis of heavy metals: $\mathrm{Cd}, \mathrm{Pb}, \mathrm{Fe}, \mathrm{Mn}, \mathrm{Zn}, \mathrm{Cr}$, $\mathrm{Cu}$ and $\mathrm{Ni}$ by atomic absorption spectrometer.

$>$ Level of soil and food contamination.

$>$ Multivariate statistical approach.

$>$ Bio-accumulation of metals from soil to food crop.

$>$ Assessment of human health risk.

Keywords Bangladesh · Ship breaking activities · Soils and food crops · Heavy metals - Multivariate approach . Transfer coefficient $\cdot$ Human health risks

\section{Introduction}

Ship breaking is commonly referred to as the complete or partial dismantling of the vessels in order to recover materials such as steel and scrap iron for recycling and reuse [1, 2]. It includes an extensive extent of challenging activities, starting from the removal of all equipments and gear to cutting down and recycling the vessel structure. Ship scrapping activities have been held responsible for polluting the adjacent environment [3, 4]. A scrapping vessel generates a large amount of waste and hazardous substances [3,5], along with lots of assets.

Ship breaking industries of Bangladesh are mainly located near the Sitakunda coastal strip of northwest Chittagong, and recently, it has become one of the most aspiring and rapidly developing industries because of having a great deal of importance of scrap iron and steel for coping with local demand. The geographical location and low labor costs are probably the main responsible factors for ranking the ship breaking industries of Bangladesh as the second largest ship breaking yard in the world following
Alang, India [6]. Currently, more than 100 registered ship recycling yards and about 20 industries linked to this ship breaking are working in Sitakunda area along with approximately 40,000 industrial workers [6]. However, the process is controversial and poses human health risks, safety as well as the environmental problems [5]. The seawater and surrounding soil in the coastal area of Sitakunda, Chittagong, Bangladesh, are heavily polluted due to ship scraping activities $[4,7]$. As the vessels are scrapped on open beaches, pollutants in different forms get accumulated first on the soil surface which incrementally migrates to the tidal and sub-tidal zone with the passing of time and subsequently deposited into the deep of the seawaters reaching the sediments. The pollutants discharged from the ship scrapping industry are mainly petroleum hydrocarbons, heavy metals, and other contaminants $[3$, $8,9]$. Among all these contaminants, heavy metals constitute a major group of pollutants since they are toxic and persist in the environment $[8,9]$. The chemical forms of metals may change, but they can never be destroyed or degraded.

The contamination of soil due to heavy metals is a global environmental concern nowadays, and it is attracting much more important attention with rapid industrialization [10]. The metal-contaminated soil is the primary route of toxic metal exposure to human beings [9]. The vegetables, fruits, and crops which grow in the soils contaminated with metals are susceptible to the metal accumulation from soils and vice versa $[9,10]$ and cause potential human health risks [11]. However, the metal accumulation process in plants varies with plant species, soil properties as well as selectivity and metal permissibility $[8,10]$. Therefore, the enrichment of metals in the plant species is usually ascertained by the accumulation factor which expresses the metal concentrations in the soil with respect to the plants [12-15]. The uptake of metals by food crops at a level large enough to cause a potential human health risk, due to excessive metal contamination in agricultural soils around the ship breaking areas, is of great concern in recent years [9]. Dietary intake of metal-contaminated fruits and vegetables poses a serious health risk to the consumers [16] and is considered the most probable key route of human exposure, although inhalation contributes vitally in the heavily contaminated site $[11,17]$. Even at trace level, toxic elements can be highly deleterious when ingested over a longer period of time [17]. Although $\mathrm{Cu}$ and $\mathrm{Zn}$ are naturally essential metals [17], when their amounts in feed plants and foods become excessive, their toxic impacts are of great health concern to animals and humans due to their tendency of bioaccumulation $[17,18]$. Furthermore, metal-contaminated food consumption can lead to serious depletion of even several essential nutrients in the human body causing severe health hazards [11]. Human health risks are most commonly enumerated 
based on the metal concentration in edible parts of the food crops compared with the reference dose and the consumer's intake/body weight $[16,19]$.

The contamination of agricultural soil and crops with heavy metals is one of the most serious environmental as well as ecological problems worldwide [16], especially in developing countries like Bangladesh [4, 9]. Here, the assessment of health risk and daily dietary intake due to heavy metals based on the regular food consumption studies is very crucial for both the children and the adult [20]. Several studies showed an elevated level of heavy metals in human-edible food crops which are grown in the contaminated areas of Bangladesh and some other countries due to industrial activities such as power plants, ship breaking, and mining $[9-11,16]$. Although a number of studies have been conducted on metal contamination due to ship breaking activities $[4,7-9,21,22]$, no study has been carried out on the concentration of the metal in agricultural crops in the considered Sitakunda ship breaking industrial area of Bangladesh so far, and no work regarding transfer of metals from soil into the food chain and their impacts on human health was reported yet. The local inhabitants of the study area are consuming the considered fruits, vegetables, and rice grain on a regular basis for a long time, but no systematic research has been conducted to find out the possible health risks due to the metal contamination in these most consumable human food crops. The present research aimed (1) to investigate the contamination levels of the metals, viz. $\mathrm{Cd}, \mathrm{Pb}, \mathrm{Fe}, \mathrm{Mn}$, $\mathrm{Zn}, \mathrm{Cr}, \mathrm{Cu}$, and $\mathrm{Ni}$, in the soils and commonly grown food crops in the study area due to ship breaking activities, (2) to find out the possible sources and significant correlations among the metals with a multivariate statistical approach, (3) to assess the accumulation factor or transfer coefficient for metals, and (4) to assess the possible human health risk due to the consumption of these commonly grown food crops in the vicinity of the Sitakunda ship breaking area evaluating the rates of daily intake and the target hazard quotients. The results of this work for the first time may provide some insight into metal contamination in the soils and transfer of metals in the most commonly consumed food crops near the ship breaking area of Sitakunda, Chittagong, Bangladesh, and serve as a basis and baseline study for comparison with other food crops of Bangladesh and other countries.

\section{Materials and methods}

\subsection{Site description}

Sitakunda, an administrative unit, is situated in the north of Chittagong District of Bangladesh with a total area of $4894 \mathrm{~km}^{2}$ and lies between the coordinates of $22^{\circ} 37^{\prime}$ $\mathrm{N}$ and $91^{\circ} 39.7^{\prime} \mathrm{E}$ [23]. It has a seashore area and is one of the oldest human habitations in Bangladesh. Although Sitakunda is mostly an agricultural area, the second largest ship breaking industry in the world is located in this region which accounts for around one-half of all the steel in Bangladesh. Ship scrapping yards are mainly situated along the coast of Sitakunda (Bhatiary to Kumira) in an area of $10 \mathrm{~km}^{2}$ beach with a tidal gauge of $6 \mathrm{~m}$ stretching north of Chittagong. Geographically, our study area lies in the coordinates of $22^{\circ} 24^{\prime} \mathrm{N}$ to $22^{\circ} 32^{\prime} \mathrm{N}$ and $91^{\circ} 42^{\prime} \mathrm{E}$ to $91^{\circ} 48^{\prime}$ E (Fig. 1). This region is tropical with hot and humid summers (April to June), and this humid and warm monsoon lasts from July to September. From April to September, the south-southeasterly directed wind is predominated which then turned to the northerly and north-easterly directions from October to March with mild winters [23].

\subsection{Sampling}

Eight soil samples (SSs) and eight human-edible food samples (FSs) including fruits, vegetables, and crops were collected simultaneously from the neighboring agricultural lands of the ship breaking site of Sitakunda, Chittagong, Bangladesh, in September 2017. The SSs (SS-1 to SS-8) were randomly collected in triplicate from each site using

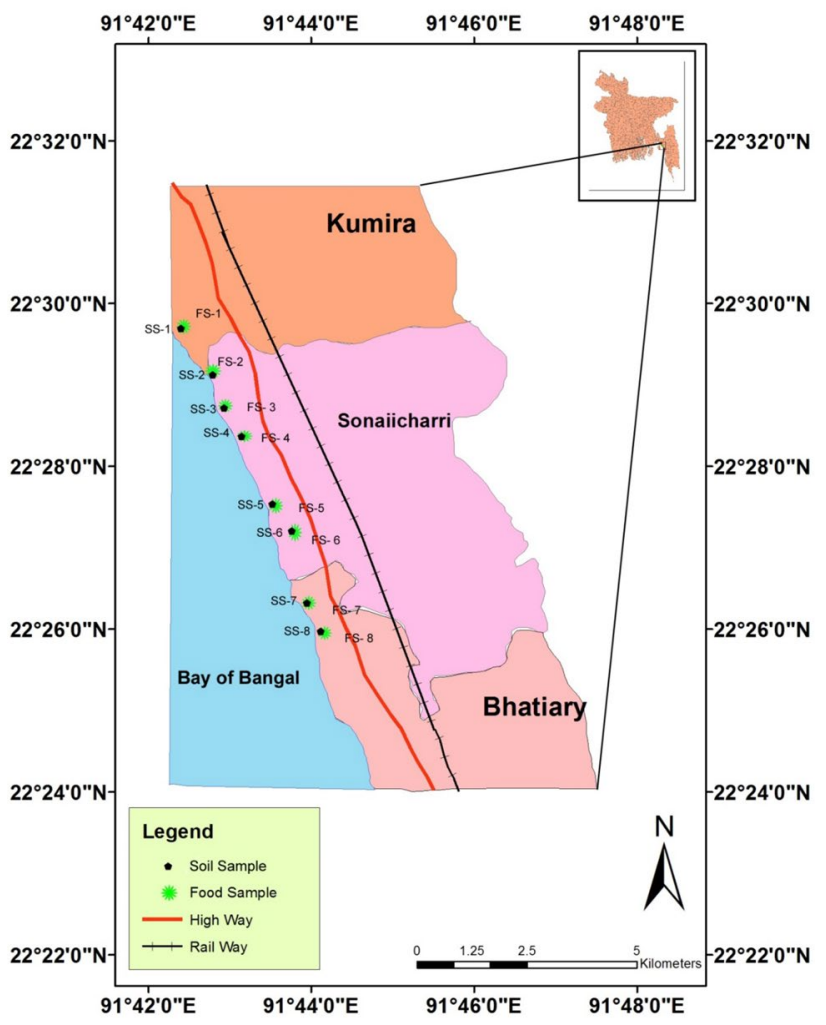

Fig. 1 Location map and sampling points of the study area 
hand auger from about $0.5 \mathrm{~m}$ depth of the soil surface at a distance of about 1-3 km each from the first sampling site in eight different locations horizontally from Kumira to Bhatiary (Fig. 1). Non-soil particles, e.g., rocks, wooden pieces, organic debris, were separated from the soil. Depending on the availability, eight different food samples, i.e., olive (Olea europaea, FS-1), ladies finger (Abelmoschus esculentus, FS-2), rice grain (Oryza sativa, FS-3), papaya (Carica papaya, FS-4), bottle gourd (Lagenaria siceraria, FS-5), guava (Psidium guajava, FS-6), teasle gourd (Momordica dioica, FS-7), and banana (Musa acuminate, FS-8), were collected from the eight different sites with hand harvesting directly from the land of the same sites as the SSs. A complete description of FSs collected from the study area with their identification numbers is given in Table 1. During sampling, three to five replicate of FSs were collected randomly from each sampling site. All collected SSs and FSs were then put immediately in cleaned airtight polyethylene bags with labels and carried to the laboratory with an icebox and stored at $4{ }^{\circ} \mathrm{C}$ until analysis [10].

\subsection{Sample analysis}

The metal content of the SSs and FSs was analyzed at ISO/IEC 17025 accredited laboratory of the Institute of National Analytical Research and Service (INARS), Bangladesh Council of Scientific and Industrial Research (BCSIR), Dhaka, Bangladesh. Prior to analysis, all SSs were air-dried naturally at room temperature followed by oven-dried at $105^{\circ} \mathrm{C}$ and then ground and homogenized [10]. The collected triplicate samples were mixed thoroughly to obtain a composite sample of a total of eight SS and sieved with a 2-mm sieve. The prepared SSs were then preserved in polyethylene bags for analysis. All FSs were first thoroughly washed with laboratory tap water followed by deionized water to remove airborne pollutants, and the edible part of the samples was cut into small pieces with a small stainless steel knife and then dried in an electric hot air oven at $80^{\circ} \mathrm{C}$ for $48 \mathrm{~h}$ to remove adhered moisture attaining a constant sample weight [10]. The dried samples were crushed up in a quartz mortar with a pestle and sieved through 2-mm nylon sieve and collected in an airtight zip lock polythene bag at $4{ }^{\circ} \mathrm{C}$ until chemical analysis was performed [10].

\subsection{Sample preparation}

About $10 \mathrm{~g}$ of finely ground dried powdered of each SS and FS was digested in 100-mL Kjeldahl flask separately with $20 \mathrm{~mL}$ concentrated nitric acid $\left(\mathrm{HNO}_{3}\right)$ and $10 \mathrm{~mL}$ perchloric acid $\left(\mathrm{HClO}_{4}\right)$ at $100 \pm 5^{\circ} \mathrm{C}$ on a heating mantle under reflux condition. The flasks were cooled, and then, the digestion was continued with the addition of $5 \mathrm{~mL}$ hydrogen peroxide $\left(\mathrm{H}_{2} \mathrm{O}_{2}\right)$ solution. After completing the digestion, indicating with an almost transparent colored solution, the flasks were removed from the heating mantle and cooled naturally. Digested samples were then transferred to $50-\mathrm{mL}$ previously cleaned volumetric flasks and diluted up to the mark with deionized water. The samples were mixed well for homogeneity and filtered through Whatman $^{\text {TM }}$ filter paper (qualitative $1,125 \mathrm{~mm} \mathrm{dia.}^{*} 100$ circles). A sample blank without adding the sample was also prepared for quality control following the same procedure as above without adding SS or FS. The samples were then stored for metal analysis in the laboratory at $4{ }^{\circ} \mathrm{C}$.

\subsection{Instrumental analysis}

The analysis of metals was performed following our previous reports [24-26] and the standard methods described by APHA [27]. The concentration of $\mathrm{Fe}, \mathrm{Mn}, \mathrm{Zn}$, and $\mathrm{Cu}$ in the SSs and FSs was determined using flame atomic absorption spectrometer (Model: AA240 FS, Varian, Australia) while $\mathrm{Cd}, \mathrm{Pb}, \mathrm{Cr}$, and Ni concentrations in the samples were analyzed using Zeeman atomic absorption spectrometer (Model: GTA 120-AA240Z, Varian, Australia) equipped with graphite furnace. During analysis, quality control method blank and standard check samples were measured sequentially. The method detection limit for $\mathrm{Fe}, \mathrm{Mn}, \mathrm{Zn}, \mathrm{Cu}, \mathrm{Cd}, \mathrm{Pb}, \mathrm{Cr}$, and $\mathrm{Ni}$ was 0.027, 0.005, 0.01, $0.01,0.00012,0.003,0.0035$, and $0.03 \mathrm{mg} \mathrm{L}^{-1}$, respectively. The spike recovery for $\mathrm{Fe}, \mathrm{Mn}, \mathrm{Zn}, \mathrm{Cu}, \mathrm{Cd}, \mathrm{Pb}, \mathrm{Cr}$, and $\mathrm{Ni}$
Table 1 List of collected FSs from the ship breaking area of Sitakunda, Chittagong, Bangladesh, with their identification numbers $(N=8)$

\begin{tabular}{lllll}
\hline English name & Vernacular name & Scientific name & Family & Sample ID \\
\hline Olive & Jalpai & Olea europaea & Oleaceae & FS-1 \\
Ladies finger (Okra) & Dherosh & Abelmoschus esculentus & Mallow/Malvaceae & FS-2 \\
Rice grain & Dhan & Oryza sativa & Graminae/Poaceae & FS-3 \\
Papaya & Pempe & Carica papaya & Caricaceae & FS-4 \\
Bottle gourd & Lau & Lagenaria siceraria & Cucurbitaceae & FS-5 \\
Guava & Peyara & Psidium guajava & Myrtaceae & FS-6 \\
Teasle gourd & Kakrol & Momordica dioica & Cucurbitaceae & FS-7 \\
Banana & Kala & Musa acuminata & Musaceae & FS-8 \\
\hline
\end{tabular}


was $97.8 \%, 95.0 \%, 99.3 \%, 98.4 \%, 97 \%, 89.5 \%, 107.6 \%$, and $100.1 \%$, respectively, and was calculated by the following formula:

Spike recovery $(\%)=\{($ Concentration of spike sample - Concentration of unspike sample $) /$ Amount of spike $\} * 100$ similarities or dissimilarities $[24,28]$ in samples. The PCA on the dataset was performed using varimax normalized rotation while the HCA to the standardized matrix
For each measurement, mean values of three consecutive replicates with relative standard deviation (RSD) less than $10 \%$ were taken. A metal-specific hollow cathode lamp $(\mathrm{HCL})$ was used in the instrument for measuring metal concentration. The details of operating conditions of the atomic absorption spectrometer instrument are given in Supplementary Table (Table S1).

\subsection{Analytical quality control}

The quality of the analysis was very carefully ensured throughout the study period starting from sample collection to analysis in the laboratory as described elaborately in our previous work [24, 25]. Analytical-grade reagents (Scharlau, Spain) such as $\mathrm{HNO}_{3}, \mathrm{HClO}_{4}, \mathrm{H}_{2} \mathrm{O}_{2}$, and deionized water (electrical conductivity $0.2 \mu \mathrm{S} \mathrm{cm}^{-1}$, resistance $18.2 \mathrm{M} \Omega \mathrm{cm}$ at $25^{\circ} \mathrm{C}$ ) were used for sample preparation. All glass wares used in the experiment including pipette and volumetric flask were calibrated, and these were cleaned prior to use by soaking in $10 \%(\mathrm{v} / \mathrm{v}) \mathrm{HNO}_{3}$ overnight and then rinsed with deionized water. A highly precise calibrated digital electrical balance (GR-200, A\&D Company Limited, Tokyo, Japan) was used for sample weighing. The instrument was calibrated with the certified reference material (CRM) (Fluka Analytical, Sigma-Aldrich, Germany) of $1000 \pm 4 \mathrm{mgL}^{-1}$ stock concentration as traceable to the National Institute of Standards and Technology (NIST), USA. The validity of the analytical technique was further ensured by spike recovery. Accuracy and precision of the analytical results were checked with replicate analysis against NIST traceable CRM.

\section{Data analysis}

\subsection{Statistical analysis}

The analytical data were statistically analyzed using the IBM SPSS statistics software (version 20, IBM Corporation, Armonk, NY, USA). Descriptive statistics of the parameters were computed to show their average behaviors and dispersions [24]. Multivariate statistical analysis such as principal component analysis (PCA) and hierarchical cluster analysis (HCA) was performed to obtain the elaborate information of the analytical data sets and procure an insight into the metal distribution identifying the was applied using Ward's method [20], and the results are expressed with a dendrogram to represent a system of organized variables in which each group exhibits common characteristics. The interrelationship among the analyzed metals in the samples was evaluated with a Pearson bivariate correlation matrix (CM) in order to identify the likely possible sources of sample contamination $[24,26]$. For other analytical calculations, Microsoft Excel 2013 was frequently used.

\subsection{Quantification of soil pollution}

The most commonly used quantitative methods for soil contamination assessment are enrichment factor (EF), geo-accumulation index $\left(I_{\text {geo }}\right)$, and contamination factor (CF).

\subsubsection{Enrichment factor (EF)}

In order to estimate the impact of anthropogenic contribution to the soil contaminations, a most commonly employed approach is to evaluate the normalized enrichment factor (EF) for metal contamination levels above the levels of uncontaminated background [12, 29, 30]. According to Taylor [31], the enrichment factor for every single metal in the sample is enumerated by dividing its concentration ratio to the normalizing element by the same ratio obtained in the chosen baseline and is commonly computed following the relationship:

$\mathrm{EF}=\frac{(\text { Metal } / \mathrm{Fe})_{\text {sample }}}{(\text { Metal } / \mathrm{Fe})_{\text {background }}}$

In this count, iron $(\mathrm{Fe})$ was taken as the reference element for geochemical normalization due to its association with fine solid surfaces, similar geochemistry to that of many trace metals, and it is the most uniform natural concentration [30]. The degree of metal pollution using enrichment factor can be categorized into seven-factor classes [31] which are: $\mathrm{EF}<1$ (no enrichment); $1 \leq \mathrm{EF}<3$ (minor enrichment); $3 \leq \mathrm{EF}<5$ (moderate enrichment); $5 \leq \mathrm{EF}<10$ (moderately severe enrichment), $10 \leq \mathrm{EF}<25$ (severe enrichment); $25 \leq \mathrm{EF}<50$ (very severe enrichment); $E F>50$ (extremely severe enrichment). 


\subsubsection{Geo-accumulation index $\left(I_{\text {geo }}\right)$}

The geo-accumulation index $\left(I_{\text {geo }}\right)$ for analyzed metal concentrations was originally expressed by Muller [32] using the equation:

$I_{\text {geo }}=\frac{\log _{2}\left(C_{n}\right)}{1.5\left(B_{n}\right)}$

where $C_{\mathrm{n}}$ is the studied metal concentration from analysis and $B_{\mathrm{n}}$ is the geochemical background concentration of that metal. Factor 1.5 is the correction factor of the background matrix due to lithospheric effects. According to Muller [33], the geo-accumulation index comprises of seven grades or classes: Class 0 (practically uncontaminated): $I_{\text {geo }} \leq 0$; Class 1 (uncontaminated to moderately contaminated): $0<I_{\text {geo }}<1$; Class 2 (moderately contaminated): $0<I_{\text {geo }}<2$; Class 3 (moderately to heavily contaminated): $2<I_{\text {geo }}<3$; Class 4 (heavily contaminated): $3<I_{\text {geo }}<4$; Class 5 (heavily to extremely contaminated): $4<I_{\text {geo }}<5$; Class 6 (extremely contaminated): $5<I_{\text {geo }}$.

\subsubsection{Contamination factor (CF)}

The contamination factor (CF) may be defined as the ratio of the concentration of each analyzed metal in the soil and their background value [30] as below:

$\mathrm{CF}=\frac{C_{\text {heavy metal }}}{C_{\text {background }}}$

According to Muller [34], the levels of metal contamination are classified based on their intensities on a scale ranging from 1 to $6(0=$ none, $1=$ none to medium, $2=$ moderate, $3=$ moderately to strong, $4=$ strongly polluted, $5=$ strong to very strong, $6=$ very strong). The highest number indicates that the concentration of metal in the soil is 100 times greater than what would be expected in the earth's crust [30]. The data of crustal abundance according to Krauskopf and Bird [35] were used as background data for the enumeration of $\mathrm{EF}, I_{\text {geo, }}$ and $C F$ values.

\subsubsection{Transfer coefficient (TC)}

The potential ability of the plant species to transfer or accumulate a specific metal from the adhered soil with respect to its concentration in the soil substrate to their edible portions is commonly expressed as the transfer coefficient (TC) or bioaccumulation ratio (BR) and can be defined as the concentration ratio of metal in the plant material to that in the respective soil [12-15]. The coefficient was computed for each soil-plant sample to quantify the bioaccumulation effect of plant in the uptake of trace metals from the soils following the equation as below:

$\mathrm{TC}=\frac{C_{\text {plant }}}{C_{\text {soil }}}$

where $C_{\text {plant }}$ and $C_{\text {soil }}$ are the concentration of metal in the edible part of green plant and soil, respectively, on a dry weight basis. TC can control the exposure of the metal to humans through the food chain [9].

\subsubsection{Daily intake of metals (DIM)}

The daily intake of metals (DIM) generally depends on the concentration of a particular metal in the food crops and the consumption quantity of that respective food. The DIM for adults was estimated by the following equation [16]:

$\mathrm{DIM}=\frac{C_{\text {metal }} \times W_{\text {food }}}{B_{w}}$

where $C_{\text {metal }}$ is the concentration of the metal in contaminated food crops, $W_{\text {food }}$ is the average consumption per day of the respective food in the studied region, and $B_{\mathrm{w}}$ is the average body weight. The daily average intake of rice, vegetable, and fruit for adults was considered to be $372 \mathrm{~g}$, $274 \mathrm{~g}$ [11], and $200 \mathrm{~g}$ per person per day, respectively, while the average body weight for adults was considered to be $60 \mathrm{~kg}$ [11].

\subsubsection{Target hazard quotient (THQ)}

The target hazard quotient (THQ) has been acknowledged as a practical parameter for the assessment of risk related to the consumption of metal-contaminated food crops [11]. It is simply the ratio of a measured pollutant dose to the reference dose $(\mathrm{RfD})$ level of that pollutant. When the ratio is less than 1 , there will be no health risk due to the consumption of food contaminated with metal [16]. However, if the dose is equal to or greater than the RfD, the concern exposed population will experience a health risk [16]. The risk estimation using THQ was carried out according to Chien et al. [36], and the method has also been provided in the risk-based concentration table of the US EPA Region III [37]. The calculation is based on the following equation:

$\mathrm{THQ}=\frac{\mathrm{EFr} \times \mathrm{ED} \times \mathrm{FI} \times \mathrm{MC}}{\mathrm{RfD} \times \mathrm{BW} \times \mathrm{AT}} \times 10^{-3}$

where EFr is the exposure frequency (365 days year ${ }^{-1}$ ); $E D$ is the exposure duration which is equal to 70 years, since this is the life expectancy for Bangladesh peoples 
according to the demographics of Bangladesh; $\mathrm{Fl}$ is the food ingestion (g person ${ }^{-1} \mathrm{~d}^{-1}$ ); $\mathrm{MC}$ is the concentration of metal in food $\left(\mathrm{mg} \mathrm{kg}^{-1}\right)$; RfD is the oral reference dose $\left(\mathrm{mg} \mathrm{kg}^{-1} \mathrm{~d}^{-1}\right)$; BW is the average body weight for adult and equal to $60 \mathrm{~kg}$ [11]; AT is the average time for noncarcinogens ( 365 days year ${ }^{-1} \times$ number of exposure years, assuming 70 years in this work). Oral reference doses were based on $4 \mathrm{E}-02,3 \mathrm{E}-01,4 \mathrm{E}-03$, and $1 \mathrm{E}-03 \mathrm{mg} \mathrm{kg}^{-1} \mathrm{~d}^{-1}$ for $\mathrm{Cu}, \mathrm{Zn}, \mathrm{Pb}$, and $\mathrm{Cd}$, respectively $[38,39]$.

\section{Results and discussion}

\subsection{Soil contamination}

Table 2 shows the analytical results of metal concentration in the collected SSs of the studied ship breaking area (Bhatiary to Kumira) of Chittagong with their descriptive statistics and standard values. The concentration of $\mathrm{Cd}$, $\mathrm{Fe}$, $\mathrm{Mn}$, and $\mathrm{Zn}$ was found higher in all the SSs compared to the standard value, as recommended from Joint Group of Experts on the Scientific Aspects of Marine Environment Protection [40] and International Atomic Energy Agency
[41]. The concentration of $\mathrm{Pb}$ and $\mathrm{Cu}$ in almost all SSs was also higher than the standard value.

Regionally, for the rough quantitative estimation of the effect of various sources on the receptor, a most reliable and widely accepted approach of environmental geochemistry is to estimate the enrichment or pollution of metal in the studied area in comparison with the background area [12]. The results of all quantitative methods for soil pollution evaluation are provided in Table 3. Results of enrichment factor (EF) revealed that most of the SSs were severely enriched with $\mathrm{Zn}$ (9.32), severely to moderately enriched with $\mathrm{Cu}$ (3.75), and moderately enriched with $\mathrm{Pb}$ (3.09) and $\mathrm{Cd}$ (2.07). EF values between 0.05 and 1.5 indicate a natural process, i.e., the metal source is entirely the crustal materials, whereas the values higher than 1.5 suggest most likely anthropogenic sources of metals [42]. The higher values of $\mathrm{Zn}, \mathrm{Cu}, \mathrm{Pb}$, and $\mathrm{Cd}$ in the present work indicated that the soils were contaminated by these metals mainly due to an anthropogenic activity like ship breaking. The $\mathrm{EF}$ values for $\mathrm{Mn}, \mathrm{Ni}$, and $\mathrm{Cr}$ were $<1.5$, indicating that the soils in the studied ship breaking area were not significantly contaminated by these metals and their little contributions are entirely natural.

Table 2 Metal concentration $\left(\mu \mathrm{g} \mathrm{g}^{-1}\right.$ ) in SSs of the ship breaking area of Sitakunda, Chittagong, Bangladesh, with their measurement uncertainty $( \pm)(k=2)$ and descriptive statistics $(N=8)$

\begin{tabular}{|c|c|c|c|c|c|c|c|c|}
\hline & $\mathrm{Cd}$ & $\mathrm{Pb}$ & $\mathrm{Fe}$ & $\mathrm{Mn}$ & $\mathrm{Zn}$ & $\mathrm{Cr}$ & $\mathrm{Cu}$ & $\mathrm{Ni}$ \\
\hline \multicolumn{9}{|l|}{ Sample ID } \\
\hline SS-1 & $0.80 \pm 0.13$ & $28.6 \pm 8.9$ & $40,884 \pm 3270.7$ & $736.7 \pm 51.6$ & $349.4 \pm 40.5$ & $63.2 \pm 13.1$ & $414.8 \pm 29.9$ & $52.2 \pm 12.2$ \\
\hline SS-2 & $1.39 \pm 0.23$ & $287 \pm 89$ & $200,622 \pm 16,049.8$ & $2297 \pm 160.8$ & $3648.4 \pm 423.2$ & $94.2 \pm 16.6$ & $555.8 \pm 40.0$ & $82.1 \pm 19.2$ \\
\hline SS-3 & $0.14 \pm 0.02$ & $60.1 \pm 18.6$ & $237,065 \pm 18,965.2$ & $2008 \pm 140.6$ & $1300 \pm 150.8$ & $70.7 \pm 14.7$ & $335.8 \pm 24.2$ & $74.2 \pm 17.4$ \\
\hline SS-4 & $0.16 \pm 0.03$ & $19.5 \pm 6.0$ & $31,917 \pm 2553.4$ & $651.2 \pm 45.6$ & $237.3 \pm 27.5$ & $41.4 \pm 8.6$ & $46.4 \pm 3.3$ & $40.1 \pm 9.4$ \\
\hline SS-5 & $0.28 \pm 0.05$ & $30.9 \pm 9.6$ & $28,893 \pm 2311.4$ & $466.3 \pm 32.6$ & $181.6 \pm 21.1$ & $45.1 \pm 9.4$ & $32.4 \pm 2.3$ & $33.5 \pm 7.8$ \\
\hline SS-6 & $0.55 \pm 0.09$ & $61.1 \pm 18.9$ & $144,172 \pm 11,533.8$ & $1525 \pm 106.8$ & $2933 \pm 340.2$ & $113.7 \pm 23.6$ & $214.7 \pm 15.5$ & $72.5 \pm 17.0$ \\
\hline SS-7 & $0.39 \pm 0.07$ & $35.3 \pm 10.9$ & $31,529 \pm 2522.3$ & $579.4 \pm 40.6$ & $693.4 \pm 80.4$ & $51.5 \pm 10.7$ & $243.4 \pm 17.5$ & $36.3 \pm 8.5$ \\
\hline SS-8 & $0.24 \pm 0.04$ & $23.8 \pm 7.4$ & $29,039 \pm 2323.1$ & $413.6 \pm 29.0$ & $466.8 \pm 54.1$ & $37.2 \pm 7.7$ & $199.7 \pm 14.4$ & $42.7 \pm 10.0$ \\
\hline \multicolumn{9}{|l|}{ Descriptive statistics } \\
\hline Range & 1.25 & 267.5 & 208172 & 1883.4 & 3466.8 & 76.5 & 523.4 & 48.6 \\
\hline Minimum & 0.14 & 19.5 & 28,893 & 413.6 & 181.6 & 37.2 & 32.4 & 33.5 \\
\hline Maximum & 1.39 & 287 & 237,065 & 2297 & 3648.4 & 113.7 & 555.8 & 82.1 \\
\hline Sum & 3.95 & 546.3 & 744,121 & 8677.2 & 9809.9 & 517 & 2043 & 433.6 \\
\hline Mean & 0.49 & 68.3 & $93,015.1$ & 1084.7 & 1226.3 & 64.6 & 255.4 & 54.2 \\
\hline SD & 0.42 & 89.7 & $87,327.3$ & 747.7 & 1335.5 & 27.2 & 177.5 & 19.3 \\
\hline \multicolumn{9}{|l|}{ Skewness } \\
\hline Statistic & 1.60 & 2.66 & 0.93 & 0.85 & 1.27 & 0.96 & 0.38 & 0.45 \\
\hline Std. Error & 0.75 & 0.75 & 0.75 & 0.75 & 0.75 & 0.75 & 0.75 & 0.75 \\
\hline \multicolumn{9}{|l|}{ Kurtosis } \\
\hline Statistic & 2.41 & 7.28 & -1.12 & -1.18 & 0.07 & -0.12 & -0.34 & -1.86 \\
\hline Std. Error & 1.48 & 1.48 & 1.48 & 1.48 & 1.48 & 1.48 & 1.48 & 1.48 \\
\hline \multicolumn{9}{|l|}{ Standard value } \\
\hline IAEA (1990) & 0.11 & - & 27,000 & - & - & 77.2 & - & 56.1 \\
\hline GESAMP (1982) & 0.11 & 22.8 & - & 1.17 & 95 & - & 33.0 & - \\
\hline
\end{tabular}




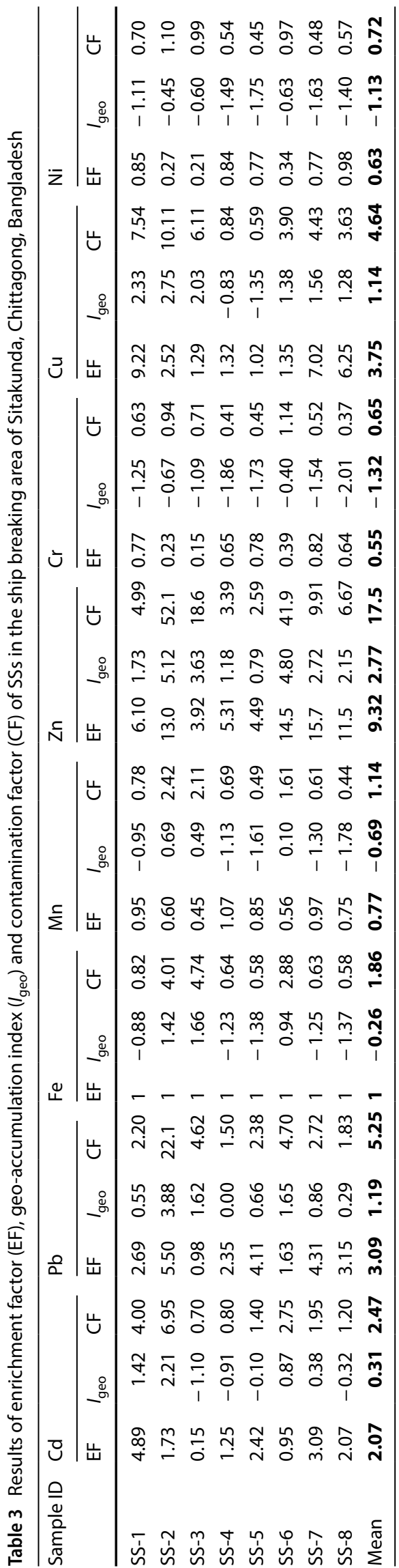

The values of the geo-accumulation index $\left(I_{\text {geo }}\right)$ were interpreted according to the classification of Muller [33], which consists of seven classes or grades (Sect. 3.2.2). The $I_{\text {geo }}$ values of $\mathrm{Zn}$ varied largely among SSs. The value of Zn in SS-2; SS-6; SS-3; SS-7 and SS-8; SS-1 and SS-4; and SS-5 fall in class 6, 5, 4, 3, 2 and 1 (Table 3 and Sect. 3.2.2), respectively. These $I_{\text {geo }}$ values inferred that the soils in the studied area were moderately to extremely contaminated by $\mathrm{Zn}$. The $I_{\text {geo }}$ values for Cu mainly fall in class 3 and class 2 (except SS-4 and 5), which deduced that Cu moderately to heavily contaminated the soils around the ship breaking area. For $\mathrm{Pb}, I_{\text {geo }}$ values also varied considerably and four soil samples (SS-1, 5, 7 and 8) fall in class 1, two soil samples (SS-3 and 6) fall in class 2 but SS- 2 fall in class-4, which showed that SSs were also contaminated moderately to heavily by Pb. I geo values of Cd for SS-2 fall in class 3, SS-1 fall in class 2, SS- 6 and 7 falls in class 1 , and the rest of the samples fell in class 0 , which indicated that $\mathrm{Cd}$ contaminated some soil samples moderately to heavily, whereas it did not contaminate other soil samples practically. These variations in $I_{\text {geo }}$ values demonstrated that the source of Cd was not natural; it was anthropogenic, obviously due to ship breaking activities of that area. From the results of $I_{\text {geo }}$ values, it is observed that the soil sample was uncontaminated to moderately contaminated by Fe and uncontaminated to slightly contaminated by $\mathrm{Mn}$ in the ship breaking area of Sitakund, Chittagong, Bangladesh, whereas no SSs were contaminated with $\mathrm{Cr}$ and $\mathrm{Ni}$ metal.

The results of the contamination factor (CF) showed that Zn contaminated most of the soil samples very strongly. The metals which showed most extensive contamination are $\mathrm{Zn}$ (ranged from 2.59 to 52.1), $\mathrm{Pb}$ (ranged from 1.50 to 22.1), and $\mathrm{Cu}$ (ranged from 0.59 to 10.1). However, in two sampling sites, CF values of $\mathrm{Cd}$ were 4.00 (SS-1) and 6.95 (SS-2), while for $\mathrm{Fe}$, the values were 4.01 (SS-2) and 4.74 (SS-3) (Table 3). The metal which showed moderate contamination was $\mathrm{Mn}$ (ranged from 0.44 to 2.42). The $\mathrm{Cr}$ and Ni metals demonstrated the lowest possible contamination level. Based on the CF values, it is found that almost all SSs in the ship breaking area of Sitakunda, Chittagong, Bangladesh, showed the highest degree of anthropogenic impact. It may also be noted that the results of $E F, I_{\text {geo }^{\prime}}$ and $\mathrm{CF}$ are very much consistent with each other strengthening the outcome of the work.

\subsection{Metals concentrations in FSs}

Table 4 shows the analytical results of metal concentration of the collected eight FSs from the ship breaking area of Sitakunda, Chittagong, Bangladesh, with their descriptive statistics. Comparing these metal concentrations with food standard of the World Health Organization (WHO) [43], it is found that the $\mathrm{Zn}$ concentration in bottle gourd, teasle 
gourd, okra, and olive exceeds the WHO limit $\left(50 \mu \mathrm{g} \mathrm{g}^{-1}\right)$ but in rice grains, banana, guava, and papaya does not exceed the WHO limit (Fig. 2a). Cadmium concentration in rice grain is at the threshold limit of the WHO standard $\left(0.20 \mu \mathrm{g} \mathrm{g}^{-1}\right)$ but in other food samples, i.e., banana, bottle gourd, guava, papaya, teasle gourd, okra, and olive, does not exceed the WHO limit (Fig. 2b). But $\mathrm{Cr}$ concentration in all food samples, i.e., rice grain, banana, bottle gourd, guava, papaya, teasle gourd, okra, and olive, in the studied ship breaking area exceeded the WHO limit $\left(1.00 \mu \mathrm{g} \mathrm{g}^{-1}\right)$ (Fig. 2c). Copper concentration in bottle gourd, guava, teasle gourd, okra, and olive exceeded the WHO limit $\left(10.00 \mu \mathrm{g} \mathrm{g}^{-1}\right)$, but Cu concentration in rice grain, banana, and papaya does not exceed the WHO limit (Fig. 2d). Lead concentration in the olive exceeded the limit while the value in teasle gourd was at the threshold limit of the WHO standard $\left(1.00 \mu \mathrm{g} \mathrm{g}^{-1}\right)$, but other food samples, i.e., rice grain, banana, bottle gourd, guava, papaya, and okra in the ship breaking area of Sitakunda, Chittagong, does not exceed the WHO limit (Fig. 2e).

\subsection{Multivariate analyses}

Principal component analysis (PCA) was used for identifying contamination sources, anthropogenic activities, or earth parent materials [24]. The results of the PCA of metal contents in SSs and FSs are presented in Table 5 and 6 , respectively. Multivariate PCA of metals in the SSs and FSs explained the cumulative variance of $89.0 \%$ and $87.6 \%$, respectively. In this study, two principal components were extracted from the analytical data of SSs which explained $51.7 \%$ and $89.0 \%$ of the variance (Fig. 3a) while three principal components were computed for FSs explaining $32.9 \%, 63.5 \%$, and $87.6 \%$ of the variance (Fig. 3b). The first principal component (PC1) for SSs showed the positive loadings of $\mathrm{Fe}, \mathrm{Mn}$, $\mathrm{Zn}, \mathrm{Cr}$, and Ni while the second component (PC2) loaded positively with $\mathrm{Cd}, \mathrm{Pb}$, and $\mathrm{Cu}$ indicated that these were originated from anthropogenic activities [21, 22]. For FSs, PC1 loaded positively with $\mathrm{Cd}, \mathrm{Mn}, \mathrm{Cr}$, and $\mathrm{Ni}$; $\mathrm{Fe}$ and $\mathrm{Zn}$ were included in the PC2; and PC3 was loaded positively with $\mathrm{Pb}$ and $\mathrm{Cu}$. Industrial emissions mainly due to ship breaking activities in the vicinity of sampling sites are mainly responsible for the contribution of these metals $[9,21,22]$. The total factor loading values of $>0.75$, $0.75-0.50$ and $0.50-0.30$ were graded as strong, moderate, and weak loading, respectively [24]. The second and third components of SSs and FSs comprised of $\mathrm{Pb}$ and Cu which were contributed predominantly by lithogenic sources [28]. The depositions of heavy dust particulates

Table 4 Metal concentration $\left(\mu \mathrm{g} \mathrm{g}^{-1}\right)$ in FSs of the ship breaking area of Sitakunda, Chittagong, Bangladesh, with their measurement uncertainty $( \pm)(k=2)$ and descriptive statistics $(N=8)$

\begin{tabular}{|c|c|c|c|c|c|c|c|c|}
\hline & $\mathrm{Cd}$ & $\mathrm{Pb}$ & $\mathrm{Fe}$ & $\mathrm{Mn}$ & $\mathrm{Zn}$ & $\mathrm{Cr}$ & $\mathrm{Cu}$ & $\mathrm{Ni}$ \\
\hline \multicolumn{9}{|l|}{ Sample ID } \\
\hline FS-1 & $0.05 \pm 0.01$ & $4.93 \pm 1.53$ & $230.1 \pm 18.4$ & $40.7 \pm 2.8$ & $59.1 \pm 6.9$ & $2.13 \pm 0.44$ & $37.9 \pm 2.7$ & $2.97 \pm 0.69$ \\
\hline FS-2 & $0.15 \pm 0.03$ & $0.28 \pm 0.09$ & $812.5 \pm 65.0$ & $20.2 \pm 1.4$ & $88.9 \pm 10.3$ & $2.02 \pm 0.42$ & $15.1 \pm 1.1$ & $1.89 \pm 0.44$ \\
\hline FS-3 & $0.20 \pm 0.03$ & $0.50 \pm 0.16$ & $130.4 \pm 10.4$ & $56.8 \pm 4.0$ & $42.3 \pm 4.9$ & $3.62 \pm 0.75$ & $5.00 \pm 0.4$ & $5.25 \pm 1.23$ \\
\hline FS-4 & $0.03 \pm 0.01$ & $0.37 \pm 0.11$ & $258.1 \pm 20.6$ & $4.83 \pm 0.34$ & $45.9 \pm 5.3$ & $2.04 \pm 0.42$ & $5.66 \pm 0.41$ & $1.72 \pm 0.40$ \\
\hline FS-5 & $0.07 \pm 0.01$ & $0.58 \pm 0.18$ & $450.5 \pm 36.0$ & $21.8 \pm 1.5$ & $82.7 \pm 9.6$ & $1.25 \pm 0.26$ & $16.4 \pm 1.2$ & $2.21 \pm 0.52$ \\
\hline FS-6 & $0.01 \pm 0.00$ & $0.33 \pm 0.10$ & $52.7 \pm 4.2$ & $8.90 \pm 0.62$ & $35.3 \pm 4.1$ & $1.68 \pm 0.35$ & $15.8 \pm 1.1$ & $1.66 \pm 0.39$ \\
\hline FS-7 & $0.07 \pm 0.01$ & $1.15 \pm 0.36$ & $813 \pm 65.0$ & $16.9 \pm 1.2$ & $118.2 \pm 13.7$ & $2.82 \pm 0.59$ & $18.9 \pm 1.4$ & $2.48 \pm 0.58$ \\
\hline FS-8 & $0.02 \pm 0.00$ & $0.56 \pm 0.17$ & $97.8 \pm 7.8$ & $97.8 \pm 6.8$ & $17.7 \pm 2.1$ & $3.09 \pm 0.64$ & $2.86 \pm 0.21$ & $2.74 \pm 0.64$ \\
\hline \multicolumn{9}{|l|}{ Descriptive statistics } \\
\hline Range & 0.19 & 4.65 & 760.3 & 93.0 & 100.5 & 2.37 & 35.0 & 3.59 \\
\hline Minimum & 0.01 & 0.28 & 52.7 & 4.83 & 17.7 & 1.25 & 2.86 & 1.66 \\
\hline Maximum & 0.20 & 4.93 & 813 & 97.8 & 118.2 & 3.62 & 37.9 & 5.25 \\
\hline Sum & 0.60 & 8.70 & 2845.1 & 267.9 & 490.1 & 18.7 & 117.6 & 20.9 \\
\hline Mean & 0.08 & 1.09 & 355.6 & 33.5 & 61.3 & 2.33 & 14.7 & 2.62 \\
\hline Standard deviation & 0.07 & 1.58 & 307.3 & 31.0 & 33.0 & 0.78 & 11.2 & 1.17 \\
\hline \multicolumn{9}{|l|}{ Skewness } \\
\hline Statistic & 1.17 & 2.67 & 0.87 & 1.48 & 0.56 & 0.43 & 1.26 & 1.96 \\
\hline Std. error & 0.75 & 0.75 & 0.75 & 0.75 & 0.75 & 0.75 & 0.75 & 0.75 \\
\hline \multicolumn{9}{|l|}{ Kurtosis } \\
\hline Statistic & 0.40 & 7.28 & -0.94 & 1.96 & -0.42 & -0.60 & 2.22 & 4.40 \\
\hline Std. error & 1.48 & 1.48 & 1.48 & 1.48 & 1.48 & 1.48 & 1.48 & 1.48 \\
\hline Standard value (WHO 1996) & 0.20 & 1.00 & - & - & 50.00 & 1.00 & 10.00 & - \\
\hline
\end{tabular}


Fig. 2 Distribution of $\mathrm{Zn}(\mathbf{a})$, $\mathrm{Cd}(\mathbf{b}), \mathrm{Cr}(\mathbf{c}), \mathrm{Cu}(\mathbf{d})$, and $\mathrm{Pb}(\mathbf{e})$ concentration in FSs collected from the ship breaking area of Sitakunda, Chittagong, Bangladesh, and its comparison with WHO limits. The solid line means WHO standard for food
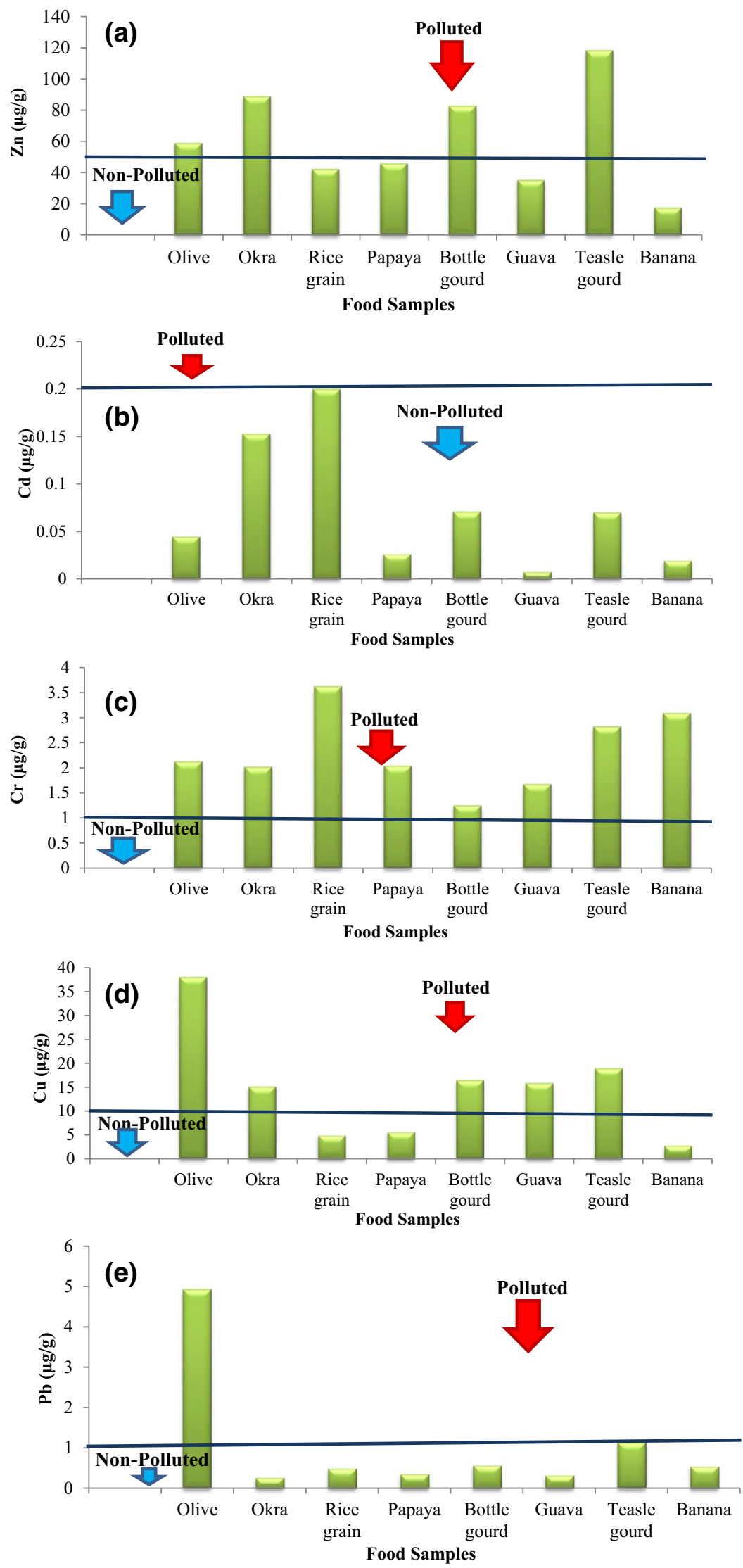
Table 5 Varimax rotated principal component analysis and communalities of the metals of the SSs

\begin{tabular}{lrrl}
\hline Parameters & \multicolumn{1}{l}{ PC1 } & \multicolumn{1}{l}{ PC2 } & Communalities \\
\hline $\mathrm{Cd}$ & 0.198 & $\mathbf{0 . 9 6 5}$ & 0.971 \\
$\mathrm{~Pb}$ & 0.459 & $\mathbf{0 . 8 0 8}$ & 0.863 \\
$\mathrm{Fe}$ & $\mathbf{0 . 9 4 7}$ & 0.193 & 0.934 \\
$\mathrm{Mn}$ & $\mathbf{0 . 9 0 2}$ & 0.383 & 0.960 \\
$\mathrm{Zn}$ & $\mathbf{0 . 7 5 2}$ & 0.555 & 0.874 \\
$\mathrm{Cr}$ & $\mathbf{0 . 7 9 6}$ & 0.372 & 0.772 \\
$\mathrm{Cu}$ & 0.407 & $\mathbf{0 . 7 8 1}$ & 0.776 \\
$\mathrm{Ni}$ & $\mathbf{0 . 8 9 8}$ & 0.399 & 0.967 \\
Eigenvalue & 6.103 & 1.013 & \\
\% of total variance & 51.652 & 37.298 & \\
Cumulative \% of variance & 51.652 & 88.950 & \\
Sampling site & & & \\
Eigenvalue & 7.999 & & \\
\% of total variance & 99.994 & & \\
Cumulative \% of variance & 99.994 & & \\
\hline
\end{tabular}

Significant values are in bold type face

Table 6 Varimax rotated principal component analysis and communalities of the metals of the FSs

\begin{tabular}{lrrrl}
\hline Parameters & \multicolumn{1}{l}{ PC1 } & \multicolumn{1}{l}{ PC2 } & \multicolumn{1}{l}{ PC3 } & Communalities \\
\hline $\mathrm{Cd}$ & $\mathbf{0 . 7 4 5}$ & 0.480 & -0.159 & 0.811 \\
$\mathrm{~Pb}$ & 0.072 & -0.096 & $\mathbf{0 . 9 8 1}$ & 0.978 \\
$\mathrm{Fe}$ & -0.066 & $\mathbf{0 . 9 3 8}$ & -0.014 & 0.885 \\
$\mathrm{Mn}$ & $\mathbf{0 . 6 1 6}$ & -0.563 & 0.005 & 0.697 \\
$\mathrm{Zn}$ & -0.082 & $\mathbf{0 . 9 4 7}$ & 0.178 & 0.936 \\
$\mathrm{Cr}$ & $\mathbf{0 . 8 6 9}$ & -0.179 & -0.153 & 0.811 \\
$\mathrm{Cu}$ & -0.212 & 0.249 & $\mathbf{0 . 9 3 3}$ & 0.977 \\
$\mathrm{Ni}$ & $\mathbf{0 . 9 4 0}$ & -0.142 & 0.086 & 0.910 \\
Eigenvalue & 3.149 & 2.057 & 1.799 & \\
\% of total variance & 32.941 & 30.606 & 24.008 & \\
Cumulative \% of vari- & 32.941 & 63.547 & 87.555 & \\
$\quad$ ance & & & & \\
Sampling site & & & & \\
Eigenvalue & 7.197 & & & \\
\% of total variance & 89.959 & & & \\
Cumulative \% of vari- & 89.959 & & & \\
$\quad$ ance & & & & \\
\hline
\end{tabular}

Significant values are in bold type face

discharged by ship breaking industries were most likely contributed to these metals in the study area from where the SSs and FSs were collected [9, 21, 22]. PCA showed that the distribution of the same kind of metals in SSs and FSs was not similar which might be due to the distinct emission and accumulation behavior of the considered metals by green plants from the source to the environment [9]. The PCA with the sampling site of SSs
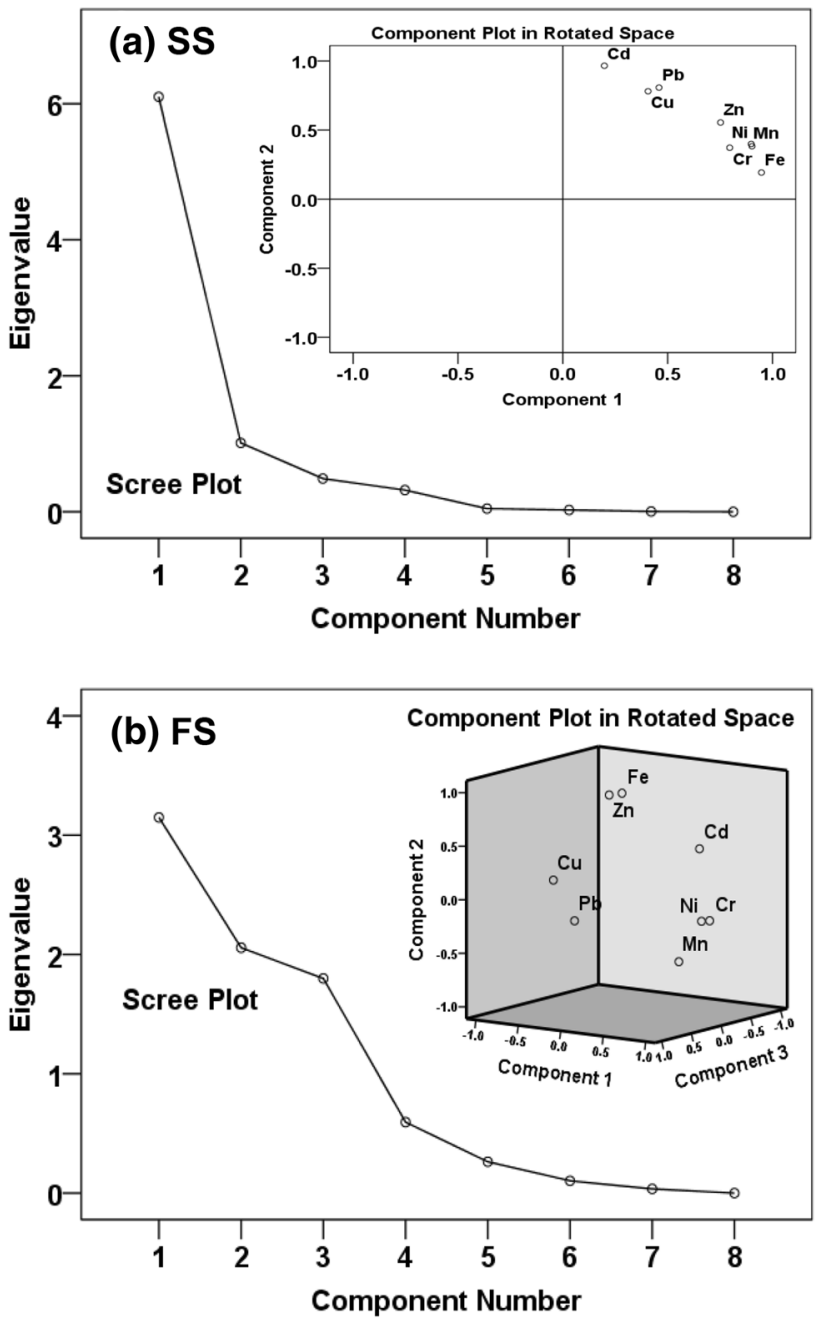

Fig. 3 Principal component analysis with scree plot and component plot in rotated space of metals in $\mathbf{a}$ SS and $\mathbf{b}$ FS collected from the ship breaking area of Sitakunda, Chittagong, Bangladesh

and FSs revealed only one component which explained $100 \%$ and $90 \%$ of the cumulative variance (Fig. 4).

Furthermore, cluster analysis (CA) was performed using Ward's method to classify the metals as well as soil sampling sites and FSs into several groups and the results are depicted with a dendrogram (Fig. 5). Two and three main clusters can be distinguished, respectively, in the dendrogram of metals of SSs (Fig. 5a) and FSs (Fig. 5b) with the phenon line set to a rescaled distance of about 15 to show statistical similarity. Cluster 1 for $\mathrm{SSs}$ included $\mathrm{Fe}, \mathrm{Mn}, \mathrm{Ni}$, $\mathrm{Zn}$, and $\mathrm{Cr}$ which showed positive loading on PC1 (Table 5) while cluster 2 contained $\mathrm{Cd}, \mathrm{Pb}$, and $\mathrm{Cu}$ loaded positively on PC2 (Table 5). For FSs, Fe and Zn grouped in cluster 1; $\mathrm{Pb}$ and $\mathrm{Cu}$ belong to cluster 2 ; and $\mathrm{Cr}, \mathrm{Ni}, \mathrm{Mn}$, and $\mathrm{Cd}$ constituted cluster 3 which showed positive loading on PC1, PC2, and PC3 (Table 6), respectively. CA of soil sampling sites showed two major classifications (Fig. 6a), cluster 1 

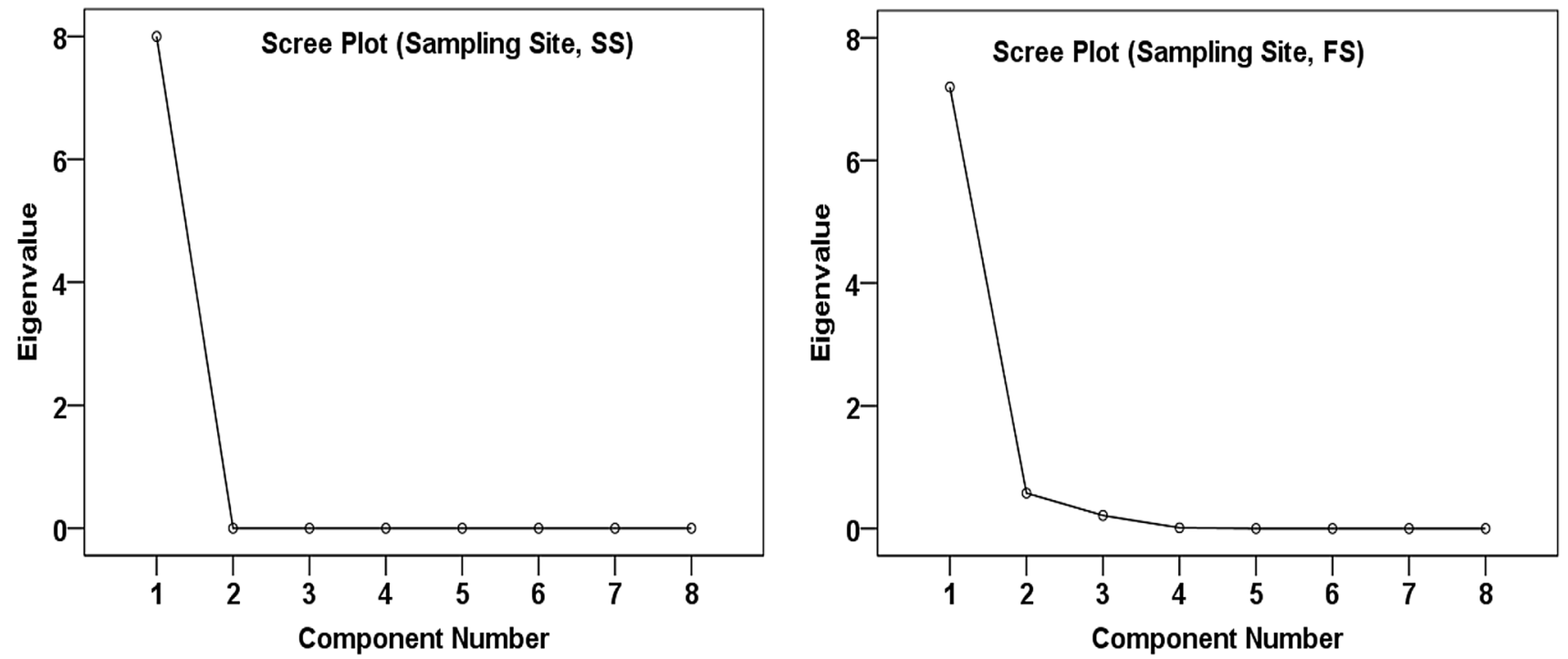

Fig. 4 Principal component analysis with scree plot of sampling sites of SS and FS collected from the ship breaking area of Sitakunda, Chittagong, Bangladesh

composed of SS-1, 4, 5, 7, and 8, and cluster 2 includes SS-2, 3, and 6. Largely, the FSs collected from the studied area were grouped into four major statistically similar clusters. Cluster 1 comprised of Carica papaya (FS-4) and Psidium guajava (FS-6) while cluster 2 consisted of Abelmoschus esculentus (FS-2), Lagenaria siceraria (FS-5), and Momordica dioica (FS-7). Cluster 3 comprised of only one species, Olea europaea (FS-1), and lastly, cluster 4 comprised of Oryza sativa (FS-3) and Musa acuminate (FS-8). The FSs in these clusters showed a congruence based on their distribution of respective metal concentration suggesting their comparable nutritional values [21, 22].
Moreover, some FSs form primary groups/clusters of similar nature (Fig. 6b) on the basis of their metal concentrations demonstrating strong significant correlations with each other.

Correlation coefficient matrix (CM) among the analyzed metal concentration in the SSs and FSs was investigated to find their inter relationships, and the results are shown in Table 7. In the case of SSs, Cd showed strong significant positive correlations with $\mathrm{Pb}(r=0.846, P<0.01)$ and $\mathrm{Cu}(r=0.798, P<0.05)$, whereas it showed insignificant associations with $\mathrm{Fe}(r=0.344)$. Iron showed strong significant positive correlations with $\mathrm{Mn}(r=0.972, P<0.01), \mathrm{Zn}$
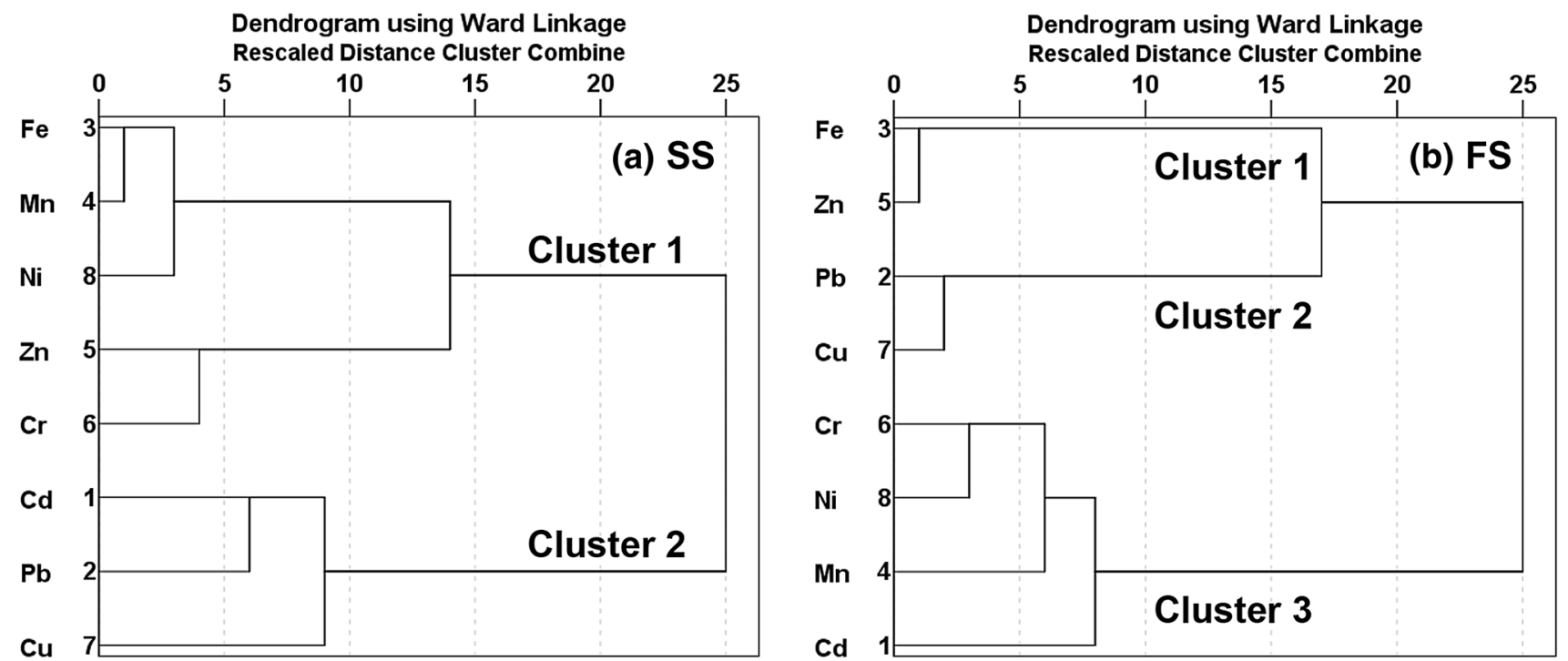

Fig. 5 Cluster analysis of the metals of $\mathbf{a}$ SS and $\mathbf{b}$ FS collected from the ship breaking area of Sitakunda, Chittagong, Bangladesh 

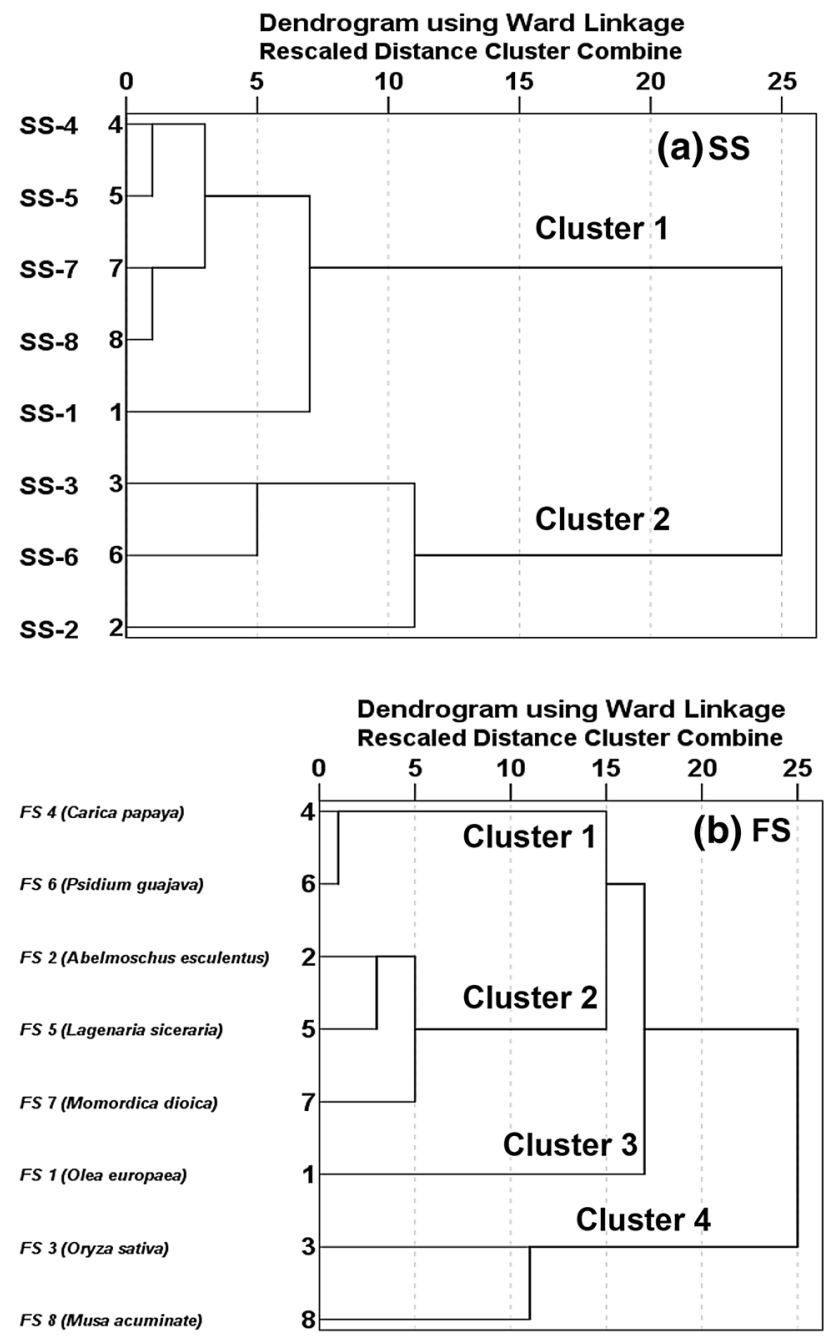

Fig. 6 Cluster analysis of a the soil sampling sites and b FS collected from the ship breaking area of Sitakunda, Chittagong, Bangladesh

$(r=0.751, P<0.05), \mathrm{Cr}(r=0.715, P<0.05)$, and $\mathrm{Ni}(r=0.930$, $P<0.01)$. Similar behavior of the metal groups indicates a mutual relationship among themselves sharing their common origin in the soil [30]. In FSs, strong significant positive correlations were demonstrated between $\mathrm{Pb}$ and $\mathrm{Cu}(r=0.857, P<0.01)$; Fe and $\mathrm{Zn}(r=0.927, P<0.01)$; and $\mathrm{Cr}$ and $\mathrm{Ni}(r=0.767, P<0.05)$. Mn showed significant positive correlations with $\mathrm{Cr}(r=0.649)$ and $\mathrm{Ni}(r=0.544)$. Similarly, $\mathrm{Cd}$ showed a significant positive correlation with $\mathrm{Ni}(r=0.669)$. The results of CM for both SSs and FSs are agreed well with the outcome of their respective PCA and $C A$, strengthening the common pathways of the metals.

\subsection{Transfer of metals from soils to food crops}

The results of the transfer coefficient (TC) of metals (Table 8) showed that the TC values of $\mathrm{Cd}, \mathrm{Zn}$, and $\mathrm{Cu}$ for most of the FSs like rice, vegetables, and fruits are higher than the other metals which are very much consistent with their concentrations in the soil samples indicating accumulations. The values of $\mathrm{Pb}$ for olive and $\mathrm{Mn}$ for bottle gourd, banana, and olive showed considerable accumulation. The TC of $\mathrm{Cr}$ for banana, teasle gourd, papaya, and rice grain while Ni for the banana, teasle gourd, bottle gourd, rice grain, and olive also showed little transfer. Iron showed the lowest transfer for all samples. In FSs, the range of $\mathrm{TC}$ values of $\mathrm{Cd}, \mathrm{Pb}, \mathrm{Fe}, \mathrm{Mn}, \mathrm{Zn}, \mathrm{Cr}, \mathrm{Cu}$, and $\mathrm{Ni}$ is $0.015-1.429,0.001-0.172,0.000-0.026,0.006-0.237$, $0.012-0.455,0.015-0.083,0.014-0.507$, and $0.023-0.071$, respectively (Table 8). The results of TC values of FSs for these analyzed metals follow the order: $\mathrm{Cd}>\mathrm{Zn}>\mathrm{Cu}>\mathrm{N}$ $\mathrm{i}>\mathrm{Cr}>\mathrm{Mn}>\mathrm{Pb}>\mathrm{Fe}$, which was nearly uniform with the results of other studies [11].

The soil samples were mostly contaminated with $\mathrm{Cd}, \mathrm{Pb}$, $\mathrm{Zn}$, and $\mathrm{Cu}$; however, the TC values for $\mathrm{Pb}$ in almost all $\mathrm{FSs}$ were significantly lower than for $\mathrm{Cd}, \mathrm{Zn}$, and $\mathrm{Cu}$, indicating that the transfer of these metals $(\mathrm{Cd}, \mathrm{Zn}$, and $\mathrm{Cu})$ from soil to plant is much easier than $\mathrm{Pb}$. This is due to their weak sorption in soils and natural availability of the ionic forms of these metals $[10,14,44]$. The higher values of TC of $\mathrm{Cd}$ and $\mathrm{Zn}$ for leafy vegetables such as okra, bottle gourd, and teasle gourd were strongly consistent with the findings of Khan et al. [45] for Brassica species. The relatively lower transfer of $\mathrm{Pb}$ from soil to plant indicated by the lower TC values is supported by the findings of Zhou et al. [46] in which they claimed that $\mathrm{Pb}$ concentration in the soil is not the potential source of this metal in the edible part of the leafy vegetables.

Furthermore, $\mathrm{Cd}$ showed the highest TC values among all the studied metals. Cadmium is considered as an intensively accumulated metal [14]. The high accumulation of this metal in plants is due to the fact that the ionic radii of $\mathrm{Cd}, \mathrm{Zn}$, and $\mathrm{Cu}$ are very close and they function almost in a similar fashion in nucleic acid metabolism [15]. Once the Cd enters into the plant cell, it interacts with the enzymes and takes the place of $\mathrm{Zn}$ which results in an easy transfer of this metal from soil to the edible part of the plant species compared to $\mathrm{Zn}[11,15]$. Moreover, $\mathrm{Cd}$ showed high accumulation in rice grain than other FSs and this might be corroborated to the vacuolar sequestration capacity in rice roots contributing to the long-distance transportation of $\mathrm{Cd}$ from roots to shoots and the metal hyperaccumulators showing a high accumulation of $\mathrm{Cd}$ in the rice grain without any visual effects $[47,48]$. The transfer of $C d$ is the most threatening due to its high toxicity.

Although the SSs were found to be moderately contaminated with $\mathrm{Cd}$ (Table 2) with higher TC values for FSs, the FSs showed low enrichment of this metal and its concentrations in the FSs (except rice grain) are still beyond the WHO standard limit (Table 4) [43]. In fact, the ability 
Table 7 Pearson's correlation matrix among of the metals of the SSs and FSs

\begin{tabular}{|c|c|c|c|c|c|c|c|c|}
\hline Parameters & $\mathrm{Cd}$ & $\mathrm{Pb}$ & $\mathrm{Fe}$ & $\mathrm{Mn}$ & $\mathrm{Zn}$ & $\mathrm{Cr}$ & $\mathrm{Cu}$ & $\mathrm{Ni}$ \\
\hline \multicolumn{9}{|l|}{ SSs $(N=8)$} \\
\hline $\mathrm{Cd}$ & 1 & & & & & & & \\
\hline $\mathrm{Pb}$ & $0.846^{a}$ & 1 & & & & & & \\
\hline $\mathrm{Fe}$ & 0.344 & 0.625 & 1 & & & & & \\
\hline $\mathrm{Mn}$ & 0.531 & $0.764^{b}$ & $0.972^{a}$ & 1 & & & & \\
\hline $\mathrm{Zn}$ & 0.700 & $0.823^{b}$ & $0.751^{b}$ & $0.846^{a}$ & 1 & & & \\
\hline $\mathrm{Cr}$ & 0.582 & 0.565 & $0.715^{b}$ & $0.779^{b}$ & $0.899^{a}$ & 1 & & \\
\hline $\mathrm{Cu}$ & $0.798^{b}$ & $0.721^{b}$ & 0.598 & 0.686 & 0.610 & 0.535 & 1 & \\
\hline $\mathrm{Ni}$ & 0.564 & 0.698 & $0.930^{\mathrm{a}}$ & $0.959^{a}$ & $0.866^{a}$ & $0.854^{a}$ & $0.725^{b}$ & 1 \\
\hline \multicolumn{9}{|l|}{ FSs $(N=8)$} \\
\hline $\mathrm{Cd}$ & 1 & & & & & & & \\
\hline $\mathrm{Pb}$ & -0.159 & 1 & & & & & & \\
\hline $\mathrm{Fe}$ & 0.312 & -0.089 & 1 & & & & & \\
\hline $\mathrm{Mn}$ & 0.085 & 0.102 & -0.408 & 1 & & & & \\
\hline $\mathrm{Zn}$ & 0.268 & 0.074 & $0.927^{a}$ & -0.521 & 1 & & & \\
\hline $\mathrm{Cr}$ & 0.436 & -0.046 & -0.152 & 0.649 & -0.219 & 1 & & \\
\hline $\mathrm{Cu}$ & -0.154 & $0.857^{a}$ & 0.214 & -0.281 & 0.405 & -0.394 & 1 & \\
\hline $\mathrm{Ni}$ & 0.669 & 0.148 & -0.289 & 0.544 & -0.201 & $0.767^{b}$ & -0.146 & 1 \\
\hline
\end{tabular}

Strong significant correlations $(r>0.70)$ are marked in bold

${ }^{a}$ Correlation is significant at the 0.01 level (two-tailed)

${ }^{b}$ Correlation is significant at the 0.05 level (two-tailed)

\begin{tabular}{llllllllll}
\hline SS ID & FS ID & $\mathrm{Cd}$ & $\mathrm{Pb}$ & $\mathrm{Fe}$ & $\mathrm{Mn}$ & $\mathrm{Zn}$ & $\mathrm{Cr}$ & $\mathrm{Cu}$ & $\mathrm{Ni}$ \\
\hline SS-1 & FS-1 & 0.056 & 0.172 & 0.006 & 0.055 & 0.169 & 0.034 & 0.091 & 0.057 \\
SS-2 & FS-2 & 0.110 & 0.001 & 0.004 & 0.009 & 0.024 & 0.021 & 0.027 & 0.023 \\
SS-3 & FS-3 & 1.429 & 0.008 & 0.001 & 0.028 & 0.033 & 0.051 & 0.015 & 0.071 \\
SS-4 & FS-4 & 0.169 & 0.019 & 0.008 & 0.007 & 0.194 & 0.049 & 0.122 & 0.043 \\
SS-5 & FS-5 & 0.254 & 0.019 & 0.016 & 0.047 & 0.455 & 0.028 & 0.507 & 0.066 \\
SS-6 & FS-6 & 0.015 & 0.005 & 0.000 & 0.006 & 0.012 & 0.015 & 0.074 & 0.023 \\
SS-7 & FS-7 & 0.179 & 0.033 & 0.026 & 0.029 & 0.170 & 0.055 & 0.078 & 0.069 \\
SS-8 & FS-8 & 0.083 & 0.023 & 0.003 & 0.237 & 0.038 & 0.083 & 0.014 & 0.064 \\
\hline
\end{tabular}

Table 8 Transfer coefficient values of metals in the collected FSs from the ship breaking area of Sitakunda, Chittagong, Bangladesh less available for plant accumulation [14]. The concentration of $\mathrm{Cr}$ in the soils and its accumulation in the studied FSs are slightly lower; however, the FSs were found to be enriched with $\mathrm{Cr}$ content. This might be attributed to the non-negligible atmospheric contributions of $\mathrm{Cr}$ around the industrial areas [12,51-53]. Generally, $\mathrm{Cr}$ does not exist in the atmosphere but can be introduced due to the burning of natural gas, oil, and high-temperature cutting and smelting of ship metal sheet around the ship breaking areas during the ship scrapping process. Depending on the temperature, moisture, oxidizing ambient atmosphere, and application circumstances, volatile hexavalent $\mathrm{Cr}$ compounds in the form of $\mathrm{CrO}_{3}\left(\sim 900^{\circ} \mathrm{C}\right.$, dry air) or $\mathrm{CrO}_{2}(\mathrm{OH})_{2}$ ( $\sim 600^{\circ} \mathrm{C}$, air containing water vapor) can be found in the atmosphere due to high-temperature industrial process [54] which then may be deposited in plants. 
According to Thornton et al. [55], a ratio of plant to soil equal to 0.1 for any metal is considered as the insignificant accumulation of that respective metal. When the soil samples are found to be enriched with a specific metal, the plant root uptakes the metal and only a part of that metal is transferred to the edible part of green leaves, giving a plant-soil ratio of about 0.2 . Therefore, the TC value of greater than 0.2 may be corroborated to the anthropogenic contribution of plant contamination [15]. From this point of view, we found that rice grain is highly contaminated with $\mathrm{Cd}$, bottle gourd is contaminated mostly with $\mathrm{Cd}, \mathrm{Zn}$, and $\mathrm{Cu}$, and banana is slightly contaminated with $\mathrm{Mn}$, due to anthropogenic activities such as ship breaking in the study area.

The overall results strongly demonstrated that the FSs like rice grain, vegetables, and fruits in the ship breaking area of Sitakunda, Bangladesh, were mostly contaminated with $\mathrm{Zn}, \mathrm{Cr}$, and $\mathrm{Cu}$. Pb contaminated the olive and teasle gourd while $\mathrm{Mn}$ contaminated the banana slightly. $\mathrm{Cd}$ contaminated the rice grain only, although its TC is high for most of the FSs.

\subsection{Health risk of local inhabitant}

The daily intake of metals (DIM) was estimated with respect to their average concentration in food crops and the consumption rate of the respective food $[11,56]$ and is given in Table 9. Perennial intake of these contaminated foods is likely to influence dangerous health effects occurring largely from $\mathrm{Pb}$ and $\mathrm{Cd}$ exposure. The weekly tolerable intake limit of $\mathrm{Pb}$ for adults recommended by the Food and Agricultural Organization [57] is $25 \mathrm{\mu g} \mathrm{kg}^{-1}$ body weight, which corresponds to $3.57 \mathrm{\mu g} \mathrm{kg}^{-1}$ body weight/day of $\mathrm{Pb}$. The dietary intake of $\mathrm{Pb}$ (1.11 to $12.3 \mu \mathrm{g} \mathrm{day}^{-1}$ ) estimated for the local inhabitants in the study area is close to the tolerable limit. The $\mathrm{Cd}$ intake of $0.03-1.24 \mu \mathrm{g} \mathrm{day}^{-1}$ through the consumption of rice, vegetables, and fruits is also less than the tolerable daily dietary intake limit $\left(7 \mu \mathrm{g} \mathrm{day}^{-1}\right)$ of FAO/WHO [56] and EFSA [58]. The estimated daily intake of Ni metal exceeded the European Food Safety Authority $\left(1.3 \mu \mathrm{g} \mathrm{kg}^{-1}\right.$ day $\left.^{-1}\right)$, and the rest of the metals are very close to the EFSA standard [58].

The results of target hazard quotient (THQ) (Table 10) for contaminated metals showed that the values of $\mathrm{Pb}$ in olive and teasle gourd and $\mathrm{Cd}$ in rice consumption were higher than 1 (THQ > 1), indicating that the local inhabitants in the studied area will be exposed to the serious health risks from $\mathrm{Pb}$ and $\mathrm{Cd}$. The THQ values of $\mathrm{Zn}$ in the vegetables such as okra, bottle gourd, and teasle gourd approached higher than 1 while the values for $\mathrm{Cu}$ in the vegetables such as okra, bottle gourd, and teasle gourd and fruits such as olive and guava were higher than 1 . These values showed that the local inhabitants around the studied ship breaking area are experiencing relatively high health risk from the dietary of $\mathrm{Cu}$ and $\mathrm{Zn}$. The THQ value of $\mathrm{Cr}$ for each $\mathrm{FS}$ was below the acceptable safety value of unity indicating a safe limit for human consumption [16]. The results also revealed that Cu was the major metal with the highest contribution to the potential non-carcinogenic health risk, and for the considered individual metals, THQ values follow the order: $\mathrm{Cu}>\mathrm{Zn}>\mathrm{Pb}>\mathrm{Cd}$. For metals with $\mathrm{THQ}>1$, the vegetables and fruits are not recommended for consumption on a regular basis [16] in order to minimize the health risk of local consumers. Thus, the overall results of the present work indicate that $\mathrm{Cu}, \mathrm{Zn}, \mathrm{Cd}$, and

Table 10 Estimated target hazard quotients for individual metals caused by the consumption of foods in the ship breaking area of Sitakunda, Chittagong, Bangladesh

\begin{tabular}{llllll}
\hline FS ID & $\mathrm{Cd}$ & $\mathrm{Pb}$ & $\mathrm{Zn}$ & $\mathrm{Cr}$ & $\mathrm{Cu}$ \\
\hline FS-1 & 0.11 & $\mathbf{3 . 0 8}$ & 0.49 & 0.004 & $\mathbf{2 . 3 7}$ \\
FS-2 & 0.70 & 0.31 & $\mathbf{1 . 3 5}$ & 0.006 & $\mathbf{1 . 7 2}$ \\
FS-3 & $\mathbf{1 . 2 4}$ & 0.78 & 0.87 & 0.010 & 0.78 \\
FS-4 & 0.09 & 0.30 & 0.51 & 0.005 & 0.47 \\
FS-5 & 0.32 & 0.67 & $\mathbf{1 . 2 6}$ & 0.004 & $\mathbf{1 . 8 8}$ \\
FS-6 & 0.03 & 0.28 & 0.39 & 0.004 & $\mathbf{1 . 3 2}$ \\
FS-7 & 0.31 & $\mathbf{1 . 3 1}$ & $\mathbf{1 . 8 0}$ & 0.009 & $\mathbf{2 . 1 6}$ \\
FS-8 & 0.07 & 0.46 & 0.20 & 0.007 & 0.24 \\
\hline
\end{tabular}

Significant values are in bold type face
Table 9 Daily intake of metals $\left(\mu \mathrm{g} \mathrm{day}^{-1}\right)$ by FSs in the ship breaking area of Sitakunda, Chittagong, Bangladesh

\begin{tabular}{lllllllll}
\hline FS ID & $\mathrm{Cd}$ & $\mathrm{Pb}$ & $\mathrm{Fe}$ & $\mathrm{Mn}$ & $\mathrm{Zn}$ & $\mathrm{Cr}$ & $\mathrm{Cu}$ & $\mathrm{Ni}$ \\
\hline FS-1 & 0.11 & 12.3 & 575.1 & 101.7 & 147.7 & 5.31 & 94.8 & 7.43 \\
FS-2 & 0.70 & 1.26 & 3710.6 & 92.1 & 406 & 9.22 & 69.0 & 8.63 \\
FS-3 & 1.24 & 3.11 & 808.4 & 352 & 262.4 & 22.4 & 31.0 & 32.6 \\
FS-4 & 0.09 & 1.22 & 860.3 & 16.1 & 153.1 & 6.80 & 18.9 & 5.74 \\
FS-5 & 0.32 & 2.66 & 2057.1 & 99.5 & 377.7 & 5.71 & 75.1 & 10.1 \\
FS-6 & 0.03 & 1.11 & 175.5 & 29.7 & 117.6 & 5.59 & 52.7 & 5.52 \\
FS-7 & 0.32 & 5.24 & 3712.6 & 77.3 & 539.7 & 12.9 & 86.4 & 11.3 \\
FS-8 & 0.07 & 1.85 & 326.1 & 326.1 & 59.0 & 10.3 & 9.53 & 9.13 \\
\hline
\end{tabular}


$\mathrm{Pb}$ were the major metals in the considered FSs contributing to the potential human health risk in the ship breaking area of Sitakunda, Chittagong, Bangladesh. However, the exposure of the inhabitants could be more than our estimations, since the present assessment of health risk includes only the most available and commonly consumed food samples in the diet.

\section{Conclusions}

Persuaded by the importance of regular monitoring and assessment and evaluating the impact of heavy metal contamination on human health due to ship breaking activities, we reported for the first time baseline data regarding the accumulation and distribution of heavy metals in the agricultural soils and food crops around the Sitakunda ship breaking industrial area of Chittagong, Bangladesh. Our study revealed that the soils around the ship breaking area are significantly contaminated with $\mathrm{Zn}, \mathrm{Cu}, \mathrm{Pb}$, and $\mathrm{Cd}$ while moderately contaminated by Fe and $\mathrm{Mn}$. Human consumable vegetables, fruits, and rice grain grown in the surrounding agricultural lands are mostly contaminated by $\mathrm{Zn}, \mathrm{Cu}$, and $\mathrm{Cr}$. The olive and teasle gourd is found to be contaminated with $\mathrm{Pb}$ while the rice grain and banana were contaminated only with $\mathrm{Cd}$ and $\mathrm{Mn}$, respectively. The multivariate statistical approach identified the anthropogenic contributions (e.g., ship breaking activities) of heavy metals in the soils and food crops. Transfer coefficient values of metals such as Cd, Zn, and Cu from soil to most of the food samples were higher than the other metals with the maximum transfer or accumulation for $\mathrm{Cd}$. Estimated daily intake of metals was very close to EFSA standard; however, the values for $\mathrm{Ni}$ metal exceeded the limit. THQ values of $\mathrm{Zn}, \mathrm{Cu}, \mathrm{Pb}$, and $\mathrm{Cd}$ for vegetables, fruits, and rice consumption evidenced a potential human health risk to the local consumers in the Sitakunda ship breaking area of Chittagong, Bangladesh.

Acknowledgements The authors are grateful to the authority of the Institute of National Analytical Research and Service (INARS), Bangladesh Council of Scientific and Industrial Research (BCSIR), Dhaka, Bangladesh, for providing laboratory facilities and other logistic support during the research period. We sincerely acknowledged Dr. Mohammad Nazim Zaman of the Institute of Mining, Mineralogy and Metallurgy (IMMM), BCSIR, Joypurhat, Bangladesh, for his valuable suggestions during this research work and manuscript preparation. We are also grateful to all staff of the analytical chemistry laboratory at INARS for laboratory assistance.

Author contributions A. H. M. S. Reza and S. Kabir conceived and designed the study. A. H. M. S. Reza and M. A. Ahsan conducted the study. A. B. Hasan, M. A. B. Siddique and M. A. Akbor contributed to the analysis. M. A. B. Siddique and A. B. Hasan interpreted analytical data and drafted the manuscript. M. A. B. Siddique and A. H. M. S. Reza further revised the draft manuscript critically for important intellectual content, and M. A. B. Siddique resolved most of the reviewer's comments. All authors read and approved the final manuscript.

\section{Compliance with ethical standards}

Conflict of interest The authors declare that they have no conflict of interest.

\section{References}

1. Rabbia HR, Rahman A (2017) Ship breaking and recycling industry of Bangladesh; issues and challenges. Proc Eng 194:254-259

2. Abdullah HM, Mahboob MG, Banu MR, Seker DZ (2012) Monitoring the drastic growth of shipbreaking yards in Sitakunda: a threat to the coastal environment of Bangladesh. Environ Monit Assess 185:383-385

3. Nøst TH, Halse AK, Randall S, Borgen AR, Schlabach M, Paul A, Rahman A, Breivik K (2015) High concentrations of organic contaminants in air from ship breaking activities in Chittagong, Bangladesh. Environ Sci Technol 49(19):11372-11380. https:// doi.org/10.1021/acs.est.5b03073

4. Hasan AB, Kabir S, Selim Reza AHM, Zaman MN, Ahsan A, Rashid $M$ (2013) Enrichment factor and geo-accumulation index of trace metals in sediments of the ship breaking area of Sitakund Upazilla (Bhatiary- Kumira), Chittagong, Bangladesh. J Geochem Explor 125:130-137

5. Hossain MS, Fakhruddin ANM, Chowdhury MAZ, Gan SH (2016) Impact of ship-breaking activities on the coastal environment of Bangladesh and a management system for its sustainability. Environ Sci Policy 60:84-94

6. Zakaria NMG, Ali MT, Hossain KA (2012) Underlying problems of ship recycling industries in Bangladesh and way forward. JNAME 9:91-102. https://doi.org/10.3329/jname.v9i2.10515

7. Hasan AB, Kabir S, Selim Reza AHM, Zaman MN, Ahsan MA, Akbor MA, Rashid MM (2013) Trace metals pollution in sea water and groundwater in the ship breaking area of Sitakund Upazilla Chittagong, Bangladesh. Mar Poll Bull 71(1-2):317-324

8. Aktaruzzaman M, Chowdhury MAZ, Fardous Z, Alam MK, Hossain MS, Fakhruddin ANM (2014) Ecological risk posed by heavy metals contamination of ship breaking yards in Bangladesh. Int J Environ Res 8(2):469-478

9. Chowdhury N, Rasid MM (2016) Heavy metal contamination of soil and vegetation in ambient locality of ship breaking yards in Chittagong, Bangladesh. J Environ Sci Toxicol Food Technol 10(10):20-27

10. Ahmad JU, Goni MA (2010) Heavy metal contamination in water, soil, and vegetables of the industrial areas in Dhaka, Bangladesh. Environ Monit Assess 166(1-4):347-357

11. Zhuang P, Murray B, McBride Xia H, Li N, Li Z (2009) Health risk from heavy metals via consumption of food crops in the vicinity of Dabaoshan mine, South China. Sci Total Environ 407(5):1551-1561

12. Wang C, Ji J, Chen M, Zhong C, Yang Z, Browne P (2017) Atmospheric contribution to boron enrichment in aboveground wheat tissues. Chemosphere 174:655-663. https://doi.org/10.1016/j. chemosphere.2017.01.124

13. Wang C, Ji J, Zhu F (2017) Characterizing Se transfer in the soilcrop systems under field condition. Plant Soil 415(1-2):535-548

14. Selinus O, Centeno JA, Finkelman RB, Fuge R, Lindh U, Smedley $P$ (2005) Essentials of medical geology: impacts of the natural environment on public health. Elsevier Academic Press, Amsterdam, pp 353-354 
15. Miclean M, Cadar O, Levei EA, Roman R, Ozunu A, Levei L (2019) Metal ( $\mathrm{Pb}, \mathrm{Cu}, \mathrm{Cd}$, and $\mathrm{Zn}$ ) transfer along food chain and health risk assessment through raw milk consumption from free-range cows. Int J Environ Res Public Health 16(21):4064

16. Miclean M, Cadar O, Levei L, Senila L, Ozunu A (2018) Metal contents and potential health risk assessment of crops grown in a former mining district (Romania). J Environ Sci Health, Part B 53(9):595-601. https://doi.org/10.1080/03601234.2018.14739 66

17. Cadar O, Miclean M, Cadar S, Tanaselia C, Senila L, Senila M (2015) Assessment of heavy metals in cows milk in Rodnei Mountains area, Romania. EEMJ 14(11):2523-2528

18. Chandra KG, Pandey P, Singh NMP, Mishra V (2011) Uptake and accumulation of potentially toxic metals ( $\mathrm{Zn}, \mathrm{Cu}$ and $\mathrm{Pb}$ ) in soils and plants of Durgapur industrial belt. J Environ Biol 32:831-838

19. USEPA (2006) USEPA region III risk-based concentration table: technical background information. Unites States Environmental Protection Agency, Washington

20. Islam MS, Ahmed MK, Al-Mamun MH (2015) Metal speciation in soil and health risk due to vegetables consumption in Bangladesh. Environ Monit Assess 187:288

21. Neser G, Kontas A, Unsalan D, Uluturhan E, Altay O, Darılmaz E, Küçüksezgin F, Tekogul N, Yercan F (2012) Heavy metals contamination levels at the Coast of Aliaga (Turkey) ship recycling zone. Marine Poll Bull 64:882-887

22. Basha S, Gaur PM, Thorat RB, Trivedi RH, Mukhopadhyay SK, Anand N, Desai SH, Mody KH, Jha B (2007) Heavy metal content of suspended particulate matter at world's largest ship-breaking Yard, Alang-Sosiya, India. Water Air Soil Pollut 178:373-384

23. Hossain MM, Islam MM (2006) Ship breaking activities and its impact on coastal zone of chittagong, Bangladesh: towards sustainable management. Advocacy \& publication unit, Young Power in Social Action (YPSA), Chittagong, Bangladesh, pp 54. ISBN: 984-32-3448-0

24. Ahsan MA, Satter F, Siddique MAB, Akbor MA, Ahmed S, Shajahan M, Khan R (2019) Chemical and physicochemical characterization of effluents from the tanning and textile industries in Bangladesh with multivariate statistical approach. Environ Monit Assess 191:575. https://doi.org/10.1007/s1066 1-019-7654-2

25. Habib M, Islam ARMT, Bodrud-Doza M, Mukta FA, Khan R, Siddique MAB, Phoungthong K, Techato K (2019) Simultaneous appraisals of pathway and probable health risk associated with trace metals contamination in groundwater from Barapukuria coal basin, Bangladesh. Chemosphere 242:125183. https://doi. org/10.1016/j.chemosphere.2019.125183

26. Islam ME, Reza AHMS, Sattar GS, Ahsan MA, Akbor MA, Siddique MAB (2019) Distribution of arsenic in core sediments and groundwater in the Chapai Nawabganj district, Bangladesh. Arab J Geosci 12(99):1-19. https://doi.org/10.1007/s1251 7-019-4272-9

27. APHA (American Public Health Association) (1998) Standard methods for the examination of water and wastewater, American Water Works Association, Water Environment Federation, USA, 22nd edition

28. Khan R, Parvez MS, Jolly YN, Haydar MA, Alam MF, Khatun MA, Sarker MMR, Habib MA, Tamim U, Das S, Sultana S et al (2019) Elemental abundances, natural radioactivity and physicochemical records of a southern part of Bangladesh: implication for assessing the environmental geochemistry. Environ Nano Monit Manag 12:100225. https://doi.org/10.1016/j.enmm.2019.10022 5

29. Kumar A, Ramanathan AL, Prabha S, Ranjan RK, Ranjan S, Singh $\mathrm{G}$ (2012) Metal speciation studies in the aquifer sediments of Semria Ojhapatti, Bhojpur District, Bihar. Environ Monit Assess 184(5):3027-3042
30. Bhuiyan MAH, Parvez L, Islam MA, Dampare SB, Suzuki S (2010) Heavy metal pollution of coal mine-affected agricultural soils in the northern part of Bangladesh. J Hazard Mater 173:384-392

31. Taylor SR (1964) Abundance of chemical elements in the continental crust: a new table. Geochim Cosmochim Acta 28(8):1273-1285

32. Muller G (1979) Schwermetalle in den sediments des RheinsVeran-derungen seitt 1971. Umschan 79:778-783

33. Muller G (1981) Die Schwermetallbelstung der sedimente des neckars und seiner nebenflusse: eine estandsaufnahme. Chem Zeitung 105:157-164

34. Muller G (1969) Index of geoaccumulation in sediments of the Rhine River. GeoJournal 2:108-118

35. Krauskopf KB, Bird DK (1995) Introduction to geochemistry, 3rd edn. McGraw-Hill Inc, New York

36. Chien LC, Hung TC, Choang KY, Yeh CY, Meng PJ, Shieh MJ, Han BC (2002) Daily intake of TBT, Cu, Zn, Cd and As for fishermen in Taiwan. Sci Total Environ 285:177-185

37. USEPA (2000) Risk-based concentration table. United States Environmental Protection Agency, Washington DC, Philadelphia

38. USEPA (1997) Integrated Risk Information System-database. USEPA, Philadelphia

39. USEPA (2007) Integrated Risk Information System-database'. USEPA, Philadelphia

40. GESAMP (Joint Group of Experts on the Scientific Aspects of Marine Environmental Protection), IMO/FAO/IJNESCO/WMO/ IAEA/UN/IJNEP (1982) The health of the oceans. Rep Stad GESAMP 15:108

41. IAEA (International Atomic Energy Agency) (1989) Trace elements in marine sediments Vienna, Austria, Reference sheet SDM-2/TM

42. Zhang J, Liu CL (2002) Riverine composition and estuarine geochemistry of particulate metals in China-weathering features, anthropogenic impact and chemical fluxes. Estuar Coastal Shelf Sci 54(6):1051-1070

43. WHO (1996) Permissible limits of heavy metals in soil and plants, vol 4. WHO, Switzerland, pp 45-67

44. Zheng N, Wang QC, Zheng DM (2007) Health risk of Hg, Pb, $\mathrm{Cd}, \mathrm{Zn}$, and $\mathrm{Cu}$ to the inhabitants around Huludao zinc plant in China via consumption of vegetables. Sci Total Environ 383(1-3):81-89

45. Khan S, Cao Q, Zheng YM, Huang YZ, Zhu YG (2008) Health risks of heavy metals in contaminated soils and food crops irrigated with wastewater in Beijing. China. Environ poll 152(3):686-692

46. Zhou H, Yang WT, Zhou X, Liu L, Gu JF, Wang WL, Zhou JL, Tian T, Peng PQ, Liao BH (2016) Accumulation of heavy metals in vegetable species planted in contaminated soils and the health risk assessment. Int J Environ Res Public Health 13:289

47. Peng J, Gong J (2014) Vacuolar sequestration capacity and longdistance metal transport in plants. Front Plant Sci 5:19

48. Ueno D, Yamaji N, Kono I, Huang CF, Ando T, Yano M, Ma JF (2010) Gene limiting cadmium accumulation in rice. Proc Natl Acad Sci 107(38):16500-16505. https://doi.org/10.1073/pnas.10053 96107

49. Cui YJ, Zhu YG, Zhai RH, Chen DY, Huang ZH, Qiu Y (2004) Transfer of metals from soil to vegetables in an area near a smelter in Nanning China. Environ Int 30(6):785-791

50. Yang Z, Chu C (2011) Towards understanding plant response to heavy metal stress. Abiotic Stress Plants Mech Adapt 10:24204

51. Bi X, Feng X, Yang Y, Li X, Shin GP, Li F, Qiu G, Li G, Liu T, Fu Z (2009) Allocation and source attribution of lead and cadmium in maize (Zea mays L.) impacted by smelting emissions. Environ Pollut 157(3):834-839

52. De Temmerman L, Ruttens A, Waegeneers N (2012) Impact of atmospheric deposition of $\mathrm{As}, \mathrm{Cd}$ and $\mathrm{Pb}$ on their concentration in carrot and celeriac. Environ Pollut 166:187-195 
53. Torkmahalleh MA, Yu CH, Lin L, Fan Z, Swift JL, Bonanno L, Rasmussen DH, Holsen TM, Hopke PK (2013) Improved atmospheric sampling of hexavalent chromium. J Air Waste Manage Assoc 63(11):1313-1323

54. Bailey J (1997) Volatile $\mathrm{Cr}$ contamination reduction in atmospheric pressure chemical vapor deposition systems by selective alloy oxidation. J Electrochem Soci 144(10):3568-3571

55. Thornton I, Farago ME (1977) Geochemistry of Arsenic. In: Abernathy CO, Calderon RL, Chappell WR (eds) Arsenic, exposure and health effects. Chapman \& Hall, London, p 27

56. Santos EE, Lauria DC, Silveira PCL (2004) Assessment of daily intake of trace elements due to consumption of food stuffs by adult inhabitants of Rio de Janeiro City. Sci Total Environ 327(1-3):69-79
57. FAO/WHO ((Food and Agriculture Organization/World Health Organization) (1989) Evaluation of certain food additives and the contaminants mercury, lead and cadmium. WHO Technical Report: 505

58. EFSA (European Food Safety Authority) (2011) Use of the EFSA comprehensive European food consumption database in exposure assessment. EFSA J 9(3):2097

Publisher's Note Springer Nature remains neutral with regard to jurisdictional claims in published maps and institutional affiliations. 